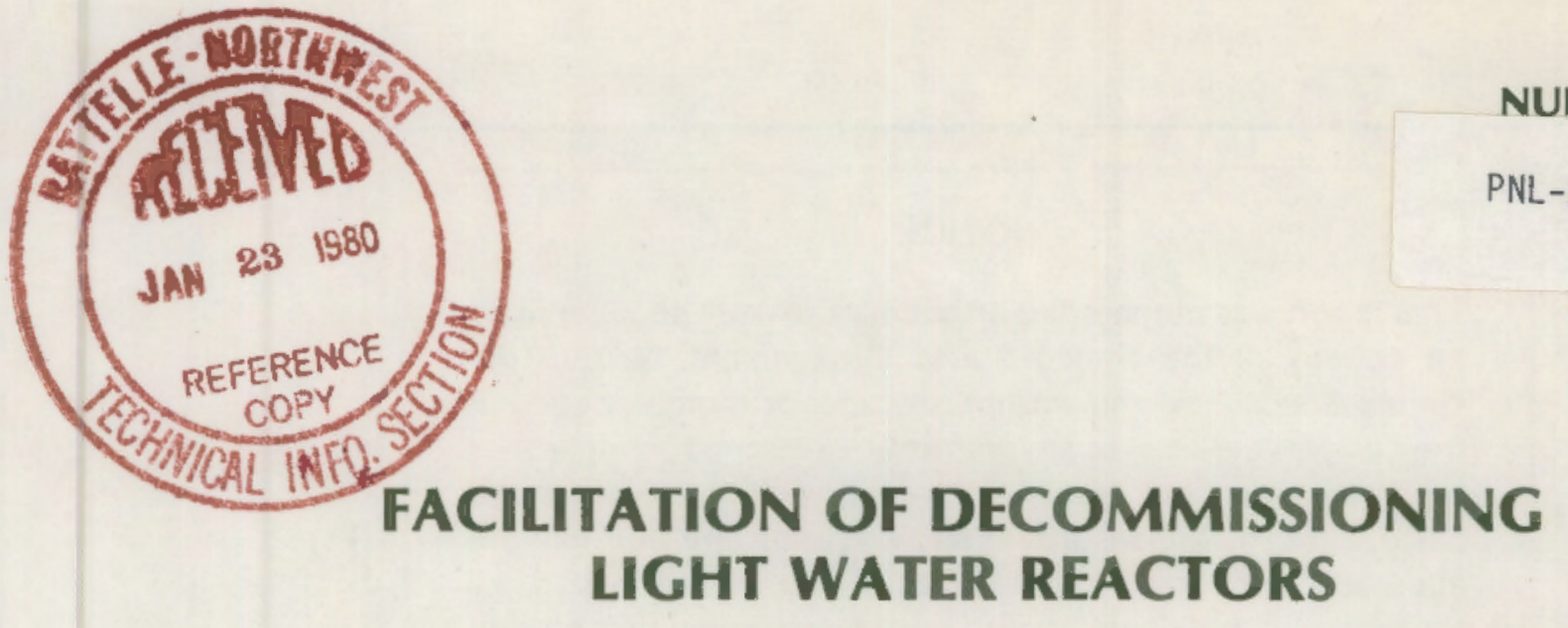

E. B. Moore, Jr.

Pacific Northwest Laboratory

Operated by

Battelle Memorial Institute

Prepared for

U.S. Nuclear Regulatory Commission 


\section{NOTICE}

This report was prepared as an account of work sponsored by an agency of the United States Government. Neither the United States Government nor any agency thereof, or any of their employees, makes any warranty, expressed or implied, or assumes any legal liability or responsibility for any third party's use, or the results of such use, of any information, apparatus product or process disclosed in this report, or represents that its use by such third party would not infringe privately owned rights.

Available from

GPO Sales Program

Division of Technical Information and Document Control

U. S. Nuclear Regulatory Commission

Washington, D. C. 20555

and

National Technical Information Service

Springfield, Virginia 22161 


\title{
FACILITATION OF DECOMMISSIONING LIGHT WATER REACTORS
}

\author{
E. B. Moore, Jr.
}

Manuscript Submitted: December 1979

Date Published: December 1979

\author{
Pacific Northwest Laboratory \\ Richland, WA 99352 \\ Operated by \\ Battelle Memorial Institute
}

Division of Engineering Standards

Office of Standards Development

U.S. Nuclear Regulatory Commission

Under NRC FIN No. B21259 



\section{STUDY CONTRIBUTORS}

E. B. Moore, Jr., Study Coordinator

M. H. Arndt (a)

G. J. Konzek

J. R. LaRiviere ${ }^{(b)}$

D. Marinos (b)

M. R. Schneller(b)

N. G. Wittenbrock

(a) Consultant.

(b) Science Applications, Inc. 



\section{FOREWORD}

by

NUCLEAR REGULATORY COMMISSION STAFF

The NRC staff is in the process of reappraising its regulatory position relative to the decomissioning of nuclear facilities. (1) As a part of this activity NRC has initiated two series of studies through technical assistance contracts. These contracts are being undertaken to develop information to support the preparation of new standards covering decommissioning.

The basic series of studies will cover the technology, safety and costs of decommissioning reference nuclear facilities. Light water reactors, fuel cycle facilities and non-fuel-cycle materials licensee facilities are included. Facilities of current design on typical sites are selected for the studies. Separate reports will be prepared as the studies of the various facilities are completed.

The first report in this series was published in FY 1977 and covered a fuel reprocessing plant. (2) The second report was published in FY 1978 and covered a pressurized water reactor. ${ }^{(3)}$ The third of the series deals with a small mixed oxide fuel fabrication plant. ${ }^{(4)}$ Additional topics will be reported on the tentative schedule as follows:

FY 1980

- Boiling Water Reactor

- Low-Level Waste Burial Ground

1. Plan for Reevaluation of NRC Policy on Decommissioning of Nuclear Facilities. îUREG-0436, Rev. 1, Office of Standards Development, U.S. Nuclear Regulatory Commission, December 1978.

2. Technology, Safety and Costs of Decommissioning a Reference Nuclear Fuel Reprocessing Plant. NUREG-0278, Pacific Northwest Laboratory for U.S. Nuclear Regulatory Commission, October 1977.

3. Technology, Safety and Costs of Decommissioning a Reference Pressurized Water Reactor Power Station. NUREG/CR-0130, Pacific Northwest Laboratory for U.S. Nuclear ReguTatory Commission, June 1978.

4. Technology, Safety and Costs of Decommissioning a Reference Small Mixed Oxide Fuel Fabrication Plant. NUREG/CR-0129, Pacific Northwest Laboratory for U.S. Nuclear ReguTatory Commission, February 1979. 
- Uranium Fabrication Plant

- Non-Fuel-Cycle Materials Licensee Facilities

- Multiple Reactor Power Stations

The second series of studies covers supporting information on the decommissioning of nuclear facilities. Three reports are planned in the second series. The first consists of an annotated bibliography on the decommissioning of nuclear facilities. (5) The second is a review and analys is of current decomissioning regulations. ${ }^{(6)}$ The following report is the third of this series, and it covers the facilitation of the decommissioning of 1 ight water reactors. The major purpose is to identify modifications or design changes to facilities, equipment and procedures which will improve safety and/or reduce costs.

The information provided in this report on facilitation, including any comments, will be included in the record for consideration by the Commission in establishing criteria and new standards for decommissioning. Persons wishing to comment on this report should mail their comments to:

Chief

Fuel Processing Systems Standards Branch

Division of Engineering Standards

Office of Standards Development

Washington, DC 20555

5. Decommissioning of Nuclear Facilities--An Annotated Bibliography. NUREG/CR-0131, Pacific Northwest Laboratory for U.S. Nuclear Regulatory Commission, September 1978.

6. Decommissioning of Commercial Nuclear Facilities: A Review and Analysis of Current Regulations. NUREG/CR-0671, Pacific Northwest Laboratory and Battelle Human Affairs Research Centers for U.S. Nuclear Regulatory Commission, August 1979. 


\section{ABSTRACT}

Information on design features, special equipment, and construction methods useful in the facilitation of deconmissioning light water reactors is presented in this report. A wide range of facilitation methods--from improved documentation to special decommissioning tools and techniques--is discussed. In addition, estimates of capital costs, cost savings, and radiation dose reduction associated with these facilitation methods are given. 



\section{SUMMARY}

This report presents information on selected design features, special equipment, and construction techniques that would facilitate decommissioning of light water reactors. The facilitation methods discussed include improved documentation, improved access to contaminated equipment, substitution of materials in pressure vessel internals, design of the biological shield for easy removal, improved techniques for protection of concrete and removal of contaminated concrete, a special shielded maintenance shop, improved shielding for maintenance and decommissioning personnel, reduction of radwaste volume by incineration, electropolishing, remote maintenance and decommissioning equipment, primary coolant system decontamination, and special decomissioning tools and techniques. Estimates are presented of capital cost and cost savings and radiation dose reduction during operational maintenance and decomissioning for all methods except primary coolant system decontamination and special decommissioning tools and techniques.

All of these facilitation methods result in a decommissioning radiation dose reduction or a decomissioning and maintenance radiation dose reduction. However, some of them are rather expensive per man-rem saved. Three methods do not give a maintenance radiation dose saving: substitution of materials in pressure vessel internals, design of the biological shield for easy removal, and improved technique for removal of concrete.

Any method that reduces radiation dose during maintenance is likely to produce a larger total dose reduction during maintenance than during decommissioning, because the opportunity for dose reduction in maintenance is much greater than in decommissioning (approximately 18,000 man-rem in maintenance over 40 years versus approximately 1000 man-rem in decommissioning over 3 or 4 years). Similarly, any method that results in less outage time for maintenance also results in an overwhelming cost savings (approximately $\$ 400,000$ per day) if replacement power must be purchased at wholesale rates.

The facilitation alternatives considered in this study and their associated costs and radiation dose reductions are summarized in Table 2.5-1. 

CONTENTS

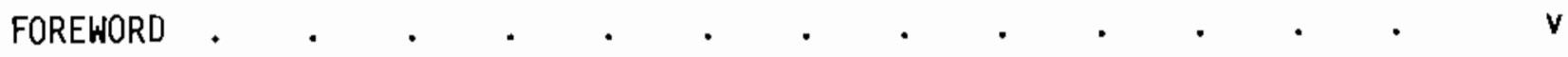

ABSTRACT . . . . . . . . . . . . . . . . . . . . . . . . . . . . . .

SUMMARY . . . . . . . . . . . . . . . . . . . . . . .

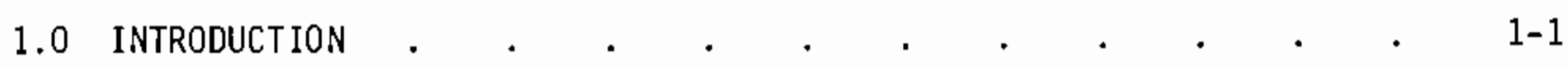

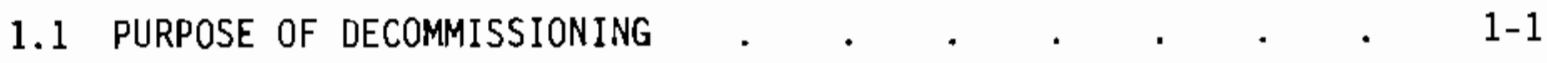

1.2 PURPOSE OF DECOMMISSIONING FACILITATION . . . . . . . 1-2

1.3 REGULATORY STATUS OF DECOMMISSIONING AND DECOMMISSIONING
FACILITIES

2.0 CRITERIA FOR EFFECTIVE DECOMMISSIONING FACILITATION . . . . $2-1$

2.1 CANDIDATE AREAS FOR FACILITATION . . . . . . . . 2-1

2.2 TIMING $\quad . \quad$. . . . . . . . . . . . . . . . $2-4$

2.3 DOSE REDUCTION CALCULATIONS . . . . . . . . . . . . 2-6

2.4 COST CALCULATIONS $\quad . \quad$.

2.5 SUMMARY OF ALTERNATIVES .

3.0 IMPROVED DOCUMENTATION . . . . . . . . . . . . . . . . . . $3-1$

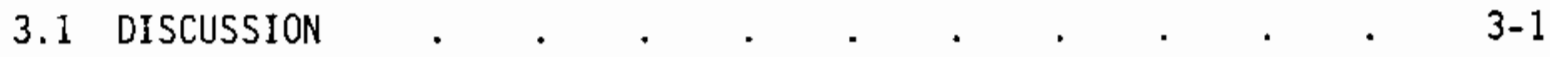

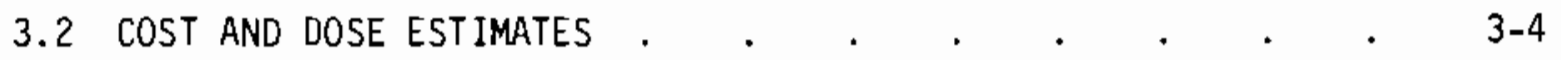

4.0 IMPROVED ACCESS TO CONTAMINATED EQUIPMENT $\quad . \quad$. . . . . . . 4-1

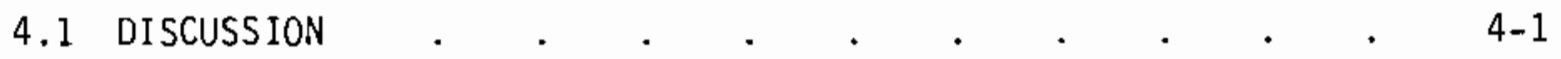

4.2 COST AND DOSE ESTIMATES . . . . . . . . . . . . . . 4-2

5.D SUBSTITUtION OF MATERIALS IN THE PRESSURE VESSEL INTERNALS • • $\quad$ 5-1

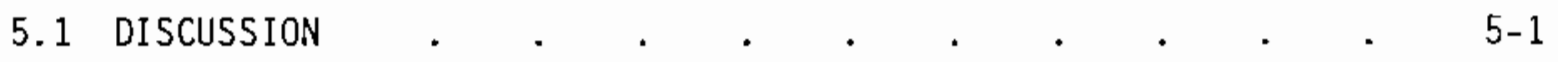

5.2 COST AND DOSE ESTIMATES . . . . . . . . . . . . . . 5-2

6.0 DESIGN OF THE BIOLOGICAL SHIELD FOR EASY REMOVAL . . . . . $6-1$ 


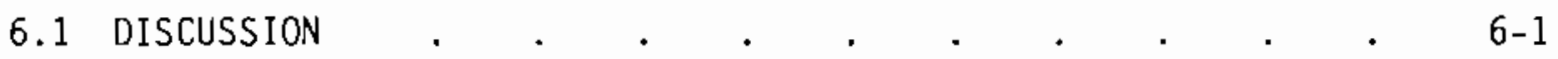

6.2 COST AND DOSE ESTIMATES FOR CASE I: PREPLACING BLASTING HOLES

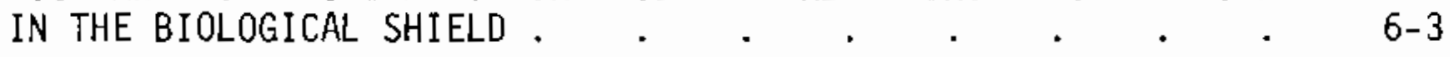

6.3 COST AND DOSE ESTIMATES FOR CASE II: MODULAR DESIGN OF THE

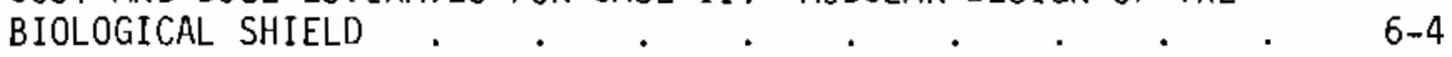

7.0 TECHNIQUES FOR IMPROVEO PROTECTION OF CONCRETE AND IMPROVED REMOVAL OF CONTAMINATED CONCRETE . . . . . . . . . . . . 7-1

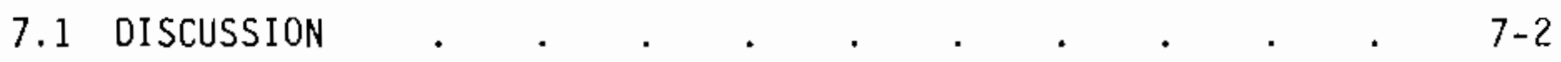

7.2 COST AND DOSE ESTIMATES FOR CASE I: CARBDN STEEL LINERS . 7-3

7.3 COST AND DOSE ESTIMATES FOR CASE II: EPOXY COATINGS . . $7-4$

7.4 COST AND DOSE ESTIMATES FOR CASE III: EMBED STEEL PLATE $\quad$ 7-5

8.0 SPECial SHIELded MAinTENANCE SHOP . . . . . . . . . 8-1

8.1 DISCUSSION

8.2 COST AND DOSE ESTIMATES . . . . . . . . . . . . .

9.0 IMPRDVEO SHIELding FOR MAINTENANCE AND OECOMMISSIONING PERSONNEL . 9-1

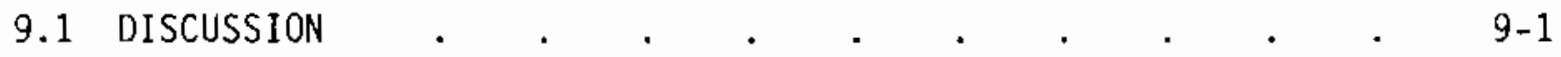

9.2 COST AND DOSE ESTIMATES FOR CASE I: PIPE SHIELDING . . $9-2$

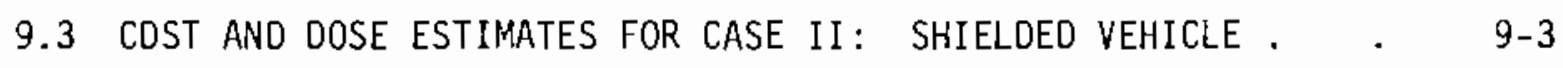

10.0 REDUCTION OF RADWASTE VOLUME BY INCINERATION . . . . . . . 10-1

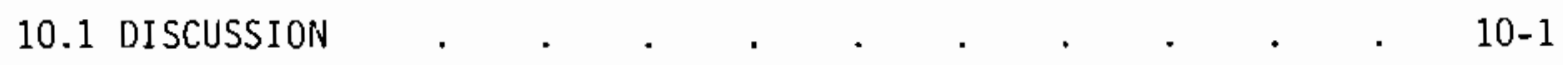

10.2 COST AND DOSE ESTIMATES . . . . . . . . . . 10-3

11.0 ELECTROPOLISHING . . . . . . . . . . . . . 11-1

11.1 DISCUSSION . . . . . . . . . . . . . . . $11-2$

11.2 COST AND DOSE ESTIMATES . . . . . . . . . . . 11-3

12.0 REMOTE MAINTENANCE AND DECOMMISSIONING EQUIPMENT . . . . . 12-1

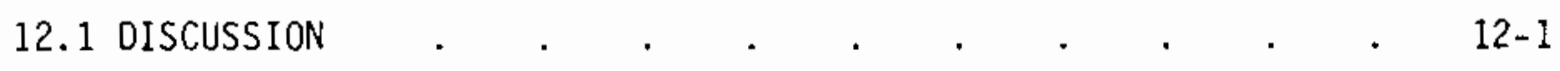

12.2 COST AND DOSE ESTIMATES . . . . . . . . . . 12-2 
13.0 PRIMARY COOLANT SYSTEM DECONTAMINATION . . . . . . . 13-1

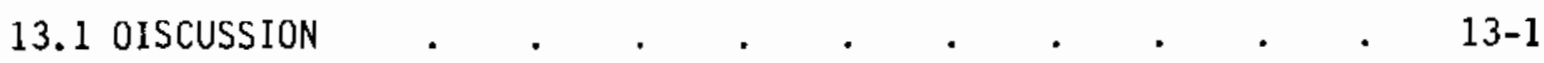

14.0 SPECIAL DECOMMISSIONING TOOLS AND TECHNIQUES . . . . . . 14-1

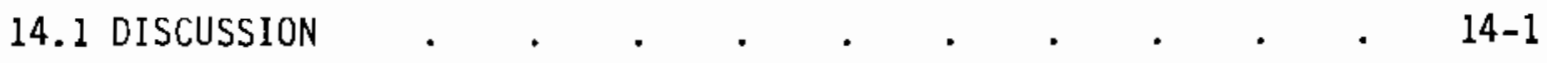

APPENDIX A $. \quad . \quad . \quad . \quad . \quad . \quad . \quad . \quad . \quad . \quad . \quad . \quad A-1$

REFERENCES . . . . . . . . . . . . . . Ref-1

\section{FIGURE AND TABLES}

6.1-1 Conceptual Design of Biological Shield . . . . . 6-2

2.1-1 Summary of the Estimated External Occupational Radiation Exposure for the Immediate Dismantlement of the Reference PWR . . . 2-2

2.1-2 Summary of Estimated Dismantlement Costs for the Reference PWR Facility . . . . . . . . . $2-3$

2.3-1 Average Annual Maintenance Personnel Radiation Dose by Work Function in 1976 . . . . . . . . . . . 2-6

2.3-2 Average Annual Radiation Dose for PWR Routine Maintenance . . 2-7

2.5-1 Summary of Decommissioning Facilitation Alternatives . . . 2-9

3.1-1 Improved Documentation . . . . . . . . . . 3-2

12.2-1 Remote Maintenance Unit Functions and Costs . . . . 12-3

A-1 Gata on burial of Activated Materials from the Containment
Building . . A-2 



\subsection{INTRODUCTION}

The development of commercial light water reactors (LWR) in the United States for the generation of electric power has given rise to a number of concerns about these reactors and about the facilities required to support them. These concerns include the safe construction and operation of all nuclear fuel cycle facilities; the safe handling, storage, and disposal of radioactive wastes; and the final disposition of reactors and other radioactive facilities. The Atomic Energy Act of 1954 gave authority to regulate these matters to the Atomic Energy Commission (AEC) and to its successor, the Nuclear Regulatory Commission (NRC). Much attention has been devoted in the past 20 years by the $A E C$ and NRC, by electric utilities, by architect-engineers, and by contractors to the safe design, construction, and operation of nuclear facilities. A substantial amount of attention is presently being devoted to the safe handling, storage, and disposal of radioactive wastes, and an increasing amount of attention is being devoted to the decommissioning of nuclear fuel cycle facilities.

The NRC's present position on decommissioning is described in NUREG-0436: Plan for Reevaluation of NRC Policy on Decommissioning of Nuclear Facilities.

This plan includes the preparation of an environmental impact statenent ${ }^{(2)}$ to accompany deconmissioning rule-making proceedings; the preparation of very extensive studies on the technology, safety and costs of decommissioning nuclear fuel cycle facilities, including studies on pressurized water reactors ${ }^{(3)}$ and boiling water reactors; ${ }^{(4)}$ and the preparation of a study on methods to facilitate the decommissioning of light water reactors. This report contains the results of the last study.

\subsection{PURPOSE OF DECOMMISSIONING}

The purpose of decommissioning nuclear fuel cycle facilities is to remove or to isolate the radioactivity associated with these facilities effectively from the environment of man. Stated differently, decommissioning means the removal of radioactivity from a facility to the point that the facility can be released to unrestricted use by the public. Methods that have been employed, or suggested, to accomplish this goal include immediate dismantlement, safe 
storage (10 to 200 years) followed by deferred dismantlement, and permanent entombment. These methods are fully discussed for reactors in References 3 and 4. They may be summarized by saying that immediate dismantlement means the removal of radioactivity to the point of unrestricted use of the facility within a few years after the facility ceases operation; safe storage followed by deferred dismantlement means dismantlement after a period of years of storage following cessation of active operation during which time the radioactivity in the facility decays safely to the point that dismantlement can take place at less cost and at lower radiation dose than in the case of immediate dis. mantlement; and permanent entombment means the sealing of the facility against intrusion and radiation leakage. Permanent entombment does not, of course, imply unrestricted release of the facility to public use, because radioactivity is still contained inside the structure. Permanent disposal of the radioactive wastes from decommissioned facilities is a 7 so necessary to complete any decommissioning activity, but consideration of this question is beyond the scope of this study.

\subsection{PURPOSE OF DECOMMISSIONING FACILITATION}

The primary purpose of decommissioning facilitation is to reduce occupational and public radiation dose during the decommissioning process, while a secondary purpose is to reduce the cost. Ideally, a facilitation procedure will also reduce radjation doses to workers and to the public during operation and maintenance; reduce the costs of construction, operation, and maintenance; and reduce the volume of radioactive wastes. Reductions will not occur in all cases, however, and costs will often be increased rather than reduced. The studies reported in References 3 and 4 , as well as other studies, have shown that radiation doses, quantities of radioactive wastes, and even costs of decomissioning can be reduced by careful planning; by appropriate changes in the design of structures, systems, components, and equipment; and by the use of special tools and techniques. Activities not related to radioactive materials and structures are considered to be standard demolition activities and are outside the scope of decommissioning. 


\subsection{REGULATORY STATUS OF DECOMMISSIONING AND DECOMMISSIONING FACILITATION}

Pursuant to the Atomic Energy Act of 1954 and its subsequent amendments, the AEC and later the NRC have promulgated regulations in Chapter I of Title 10 of the Code of Federal Regulations to administer the Act. These regulations cover the activities of the NRC, its staff, and its committees, as well as the licensing of nuclear facilities and materials. The NRC has also published regulatory guides for the purpose of providing additional guidance to applicants and licensees. Regulations and regulatory guides which specifically pertain to decommissioning are: 1) 10 CFR 50.33 (f) covering contents of application for 1 icenses, 2) 10 CFR 50.82 covering applications for termination of licenses, 3) 10 CRF 50 Appendix F covering policy relating to the siting of fuel reprocessing plants, 4) Regulatory Guide 1.86 covering termination of operating licenses for nuclear reactors, 5) Regulatory Guide 3.5 (Revision 1) covering contents of license applications for uranium mills, and 6) an NRC staff guideline (no number) issued November 1976 entit\}ed, "Guidelines for Decontamination of Facilities and Equipment Prior to Release for Unrestricted Use or Termination of Licenses for By-product, Source or Special Nuclear Material." Many other regulations and regulatory guides, such as 10 CFR 50.71(b) which covers financial reporting, apply in a general way to decommissioning. No regulation or regulatory guide specifically addresses how an owner might facilitate decomnissioning either by careful design, construction, or operation of his plant, or by the adoption of special tools and techniques, except that 10 CFR 50 Appendix $F$ does state that a "design objective for fuel reprocessing plants shall be to facilitate decontamination and removal of all significant radioactive wastes at the time the facility is permanently decommissioned."

A very useful review of existing statutes, regulations and guidelines pertaining to decommissioning appears in Reference 5. 



\subsection{CRITERIA FOR EFFECTIVE DECOMMISSIONING FACILITATION}

An effective technique for facilitating decomissioning should reduce radiation dose to decommissioning workers and/or to the public, reduce the volume of radioactive waste, or otherwise improve upon the safety of decomissioning. The technique should have little impact on or, if applicable, a beneficial impact on radiation doses received during operation and maintenance. Also, any capital costs should be offset by cost savings during operation, maintenance, and decommissioning, so that the technique is reasonably cost effective in terms of the cost per man-rem saved. The evaluations of individual techniques or procedures presented in the following sections include estimates of these impacts. Alternatives which could not reasonably be expected to reduce radiation dose during decommissioning were not evaluated.

\subsection{CANDIDATE AREAS FOR FACILITATION}

Decomissioning activities most worthy of investigation for facilitation are those for which the occupational radiation dose is greatest. Table 2.l-1 shows the occupational radiation dose expected from the immediate dismantlement of various areas of a reference 1175-MWe pressurized water reactor (PWR). Substantial opportunities for radiation dose reduction 7 ie in the dismantlement and disposal of the steam generators, of the radioactive equipment in the auxiliary building, of the primary cooling system, of the reactor pressure vesse] and its internal components, and of the radioactive concrete and other structural materials. Steam generators do not exist in a boiling water reactor (BWR); however, a similar opportunity presumably exists in decommissioning the BWR steam turbine (radioactive) and its associated piping.

It should be noted ${ }^{(3)}$ that merely waiting several decades for the dominant contaminant, ${ }^{60} \mathrm{Co}$, to decay (safe storage followed by deferred dismantlement) will reduce both the radiation dose to dismantlement workers and the cost of dismantlement, although at some increase in dose to surveillance personnel and some increase in cost for surveillance during the storage period. Safe storage followed by deferred dismantlement is thus a decommissioning facilitation alternative in and of itself. 


\section{TABLE 2.1-1. Summary of the Estimated External 0ccupational Radiation Expo- sure for the Immediate Dismantlement of the Reference PWR $(a, b)$}

\begin{tabular}{|c|c|}
\hline Description & $\begin{array}{l}\text { Dose, } \\
\text { man-rem }\end{array}$ \\
\hline \multicolumn{2}{|l|}{ Reactor Builóing } \\
\hline Move Internals to Refueling Cavity & 7.8 \\
\hline Comprehensive Predismantling Radiation Survey & 8.6 \\
\hline Segment Yessel Internals and Load Containers & 86.5 \\
\hline Segment Reactor Pressure Vessel and Load Containers & 67.1 \\
\hline Segment 5team Generators (4) and Prepare for Shipment & 118. I \\
\hline Remove RCS Pumps (4) and RCS Piping & 53.6 \\
\hline Remove Pressurizer, Relief Tank, and Safety Injection System & 50.7 \\
\hline Remove $H X^{\prime} s$ and Assorted Pumps & 22.3 \\
\hline Remove Contaminated Internal Structures & 61.6 \\
\hline Remove Spray Piping and ventilation Systems & 8.6 \\
\hline Decontaminate Remaining Internal Surfaces & 4.3 \\
\hline Reactor Building Total & 489 \\
\hline \multicolumn{2}{|l|}{ Auxiliary Building } \\
\hline Remove Electrical Equipment & 2.1 \\
\hline Decontamination (contact work and internal flushes) & 12.2 \\
\hline Remove Selected Building internals (plugs, walls, platforms) and Package & 1.3 \\
\hline Remove $I X$ Resin and Filters & 17.9 \\
\hline Remove $I X$ and Filters System Piping & 73.9 \\
\hline Remove HYAC and Fire Sprinkler Systens and Monoraits & 5.1 \\
\hline Auxiliary Building Total & 227 \\
\hline \multicolumn{2}{|l|}{ Fuel Building } \\
\hline Remove CVC System & 79.1 \\
\hline Remove Condensate Holding Tank System & $6 . ?$ \\
\hline Remove New Fuel Storage Racks and Install Electropolishing System & 1.0 \\
\hline Remove Boric Acid System, Tanks, and Piping & 30.9 \\
\hline Remove CCW System & 3.2 \\
\hline Remove Spent Fuel Racks, Fuel Transfer System, and Peripheral Equipment & 6.7 \\
\hline Remove SFP Recirculation System, Liners, and Contaminated Concrete & 6.6 \\
\hline Fuel Building Total & 134 \\
\hline \multicolumn{2}{|l|}{ Ancillaries } \\
\hline Comprehensive Plant Radiation Survey & 2.0 \\
\hline Speciar Radiation Surveys & 6.3 \\
\hline RCS and CVCS Chemical Decontamination & 25.6 \\
\hline $\begin{array}{l}\text { Decontamination (electropolishing) and Disposal (packaging and } \\
\text { shipping of contaminated equipment and debris) }\end{array}$ & 3.9 \\
\hline Packaging (combustible wastes) & 24.8 \\
\hline Miscellaneous & 170 \\
\hline Ancillaries Total & 233 \\
\hline Total for Immediate Dismantlement & 1083 \\
\hline
\end{tabular}

(a) From Reference 3, Table 11.3-1. The estimates are based on the assumption that the RCS, CVCS, and other related systems have been chemically decontaminated internally.

(b) For a detailed discussion of these estimates, consult Reference 3, Appendix G. Table G. 3-1. 
For purposes of calculating radiation dose reduction and cost savings we have assumed that immediate dismantlement is the selected mode of decommissioning. This is because the decommissioning radiation doses are largest for immediate dismantlement and because the reference PWR decomnissioning study ${ }^{(3)}$ presents itemized radiation dose and cost estimates with which to make comparisons. The costs of immediate dismantlement of the reference PWR are given in Table 2.1-2 (from Table 10.1-1 in Reference 3). Decommissioning facilitation alternatives will, for the most part, apply to other decommissioning modes as

TABLE 2.1-2. Surmary of Estimated Dismantlement Costs for the Reference PWR Facility

\section{Category}

Activated Materials Disposal

Containment Internals Disposal

other Building Internals Disposal

Waste Disposa?

Staff Labor

Electrical Power

Special Equipment

Miscellaneous Supplies

Specialty Contractors

Nuclear Insurance

Environmental Surveillance

Subtota 1

25\% Contingency

Total Dismantling Costs (rounded)
Cost in Millions of 1978 Dollars (a)
$4.534^{\text {(b) }}$
0.961
4.222
0.693
8.986
3.500
$0.822^{(c)}$
1.559
0.390
0.800
$\underline{0.154}$
26.621
6.655
33.3

(a) Number of figures shown is for computational accuracy and does not imply precision to the nearest thousand dollars.

(b) Cost differential of $\$ 1.8$ million for deep geologic disposal of highly activated reactor vessel components is included here. (See Reference 3, Appendix G.4.2.1.)

(c) See Reference 3, Table F.3-1, Appendix F, or Table I.6-1, Appendix I. 
well, but with differing impacts on radiation dose and costs. For example, accurate record keeping becomes more valuable if safe storage is to be used, because persons with first-hand knowledge of the reactor to be decomissioned will probably not be available at the time of decomissioning. Similarly, little is to be gained by reducing the cobalt content of reactor internals if they are to be entombed rather than dismantied and removed. Also, there is no point in designing and building special fixtures in the biological shield to facilitate its removal if it is to be entombed rather than removed.

\subsection{IIMING}

It is not necessary to wait until a reactor has reached the end of its operating lifetime to apply decomissioning facilitation techniques. In fact, it is required that some techniques be initiated early in the design stage if they are to be applied at all. Decommissioning facilitation techniques may be classified into the following categories, which group both timing and type of activity:

Design. Proper advance design of structures, equipment, and systems can lead to easier access for decontamination and dismantling. A standard plant design would permit the development of standard decommissioning tasks and procedures. The standard design could include provisions for a standard construction sequence and a standard dismantling or decomissioning sequence. Provision for clearly labelling and identifying all plant components during construction would be an important part of a standard plant design. These activities would necessarily need to be carried out, for the most part, in advance of construction.

Materials and Material Finishing. Careful selection and surface finishing of materials used in equipment and structures can lead to decreased problems with neutron activation, corrosion, and entrapment and concentration of radioactive particles. Elimination of ${ }^{59} \mathrm{Co}$ from steels used in pressure vessei interna? structures can reduce the amount of ${ }^{60}$ Co formed from neutron bombardment of steel. However, care must be taken that the neutrons do not go, elsewhere and create a more objectionable radioactive isotope. Chemical polishing or electropolishing of piping, equipment, and structures can remove surface 
imperfections which entrap radioactive particles. Material selection must be done during the design phase, except for components that are to be replaced from time to time.

Record Keeping. Accurate as-built drawings of the plant, photographs of construction, models, and detailed maintenance and operation records are important in planning and carrying out any decomissioning activity. Such documentation is particularly important if decommissioning is to be delayed (safe storage followed by deferred dismantlement) because personnel with experience in operating and maintaining the plant will not be available to assist with decomissioning. This activity should be conducted from initial design of the plant to the end of decomissioning.

Decontamination Techniques During Operation. Special attention to decontamination while the reactor is operating can lead to lower residual dose rates when the reactor is ready for decommissioning. This includes the obvious procedures for thorough cleanup of any radiation spills as well as less obvious procedures for decontaminating piping and equipment, such as chemical decontamination and electropolishing. While decontamination must be planned in advance (access to equipment, access ports to piping, etc.) the actual decontamination is carried out during and at the end of the operating lifetime of the plant.

Dismantling Tools, Equipment, and Techniques. Special tools, shielding, equipment, and methods can result in shorter times to dismantle various components and in less radiation exposure. Techniques, such as incineration, that could reduce the volume of radioactive material to be sent to a permanent disposal site would be valuable. Development of tools, equipment, and techniques can be done for existing plants as well as in conjunction with design of new piants.

These categories emphasize the fact that decommissioning facilitation alternatives may be planned for and applied at widely different times over a very lengthy time span of reactor design, construction, operation, and decommissioning. 


\subsection{DOSE REDUCTION CALCULATIONS}

In order to analyze various alternatives with respect to radiation dose reduction during decommissioning, comparisons were made with the estimated radiation doses for immediate dismantiement of the reference 1175-MWe PWR. These are occupational radiation doses to dismantlement workers totaling 1083 man-rem (Table 2.1-1), occupational radiation doses to the transport workers totaling 100 man-rem, and radiation doses to the public from transportation of radioactive wastes totaling 21 man-rem. ${ }^{(3)}$

To perform the same analysis with respect to radiation dose reduction during operation and maintenance, comparisons were made with the 1976 annual average occupational radiation dose of 450 man-rem per reactor from the operation, maintenance, and refueling of PWRs (Reference 6, p. 10, Table 4). Where appropriate, the 450 man-rem tota 1 was broken down according to the percentages in Table 2.3-1 and in Table 2.3-2.

TABLE 2.3-1. Average Annual Maintenance Personnel Radiation Dose by Work Function in 1976 (a)

\begin{tabular}{|c|c|c|}
\hline Work Function & $\begin{array}{l}\text { Percent } \\
\text { of Dose }\end{array}$ & $\begin{array}{cc} & \text { Fraction } \\
\times & 450 \mathrm{man}-\mathrm{rem} \\
\end{array}$ \\
\hline Reactor Operations and Surveillance & 10.4 & 47 \\
\hline Routine Maintenance & 31.7 & 143 \\
\hline In-Service Inspection & 5.7 & 26 \\
\hline Special Maintenance & 39.5 & 178 \\
\hline Waste Processing & 4.8 & 22 \\
\hline Refueling & 7.9 & 36 \\
\hline
\end{tabular}

(a) Reference 6, Table 5 .

Evidence exists that the annual occupational radiation dose from reactor operation, maintenance, and refueling is increasing, ${ }^{(8)}$ and is due both to buildup of radioactive contaminants with increasing reactor age ${ }^{(8)}$ and to increasing reactor size. ${ }^{(9)}$ Because the evidence is somewhat preliminary, we did not allow for this increase in our calculations and used the figure of 
TABLE 2.3-2. Average Annual Radiation Dose for PWR Routine Maintenance (a)

Work Function

Instrumentation and Calibration

Steam Generator Inspection and Repair

Reactor Coolant Pumps

Ma in Coolant Pumps

Main Coolant Pumps

Changing Pumps

valves

Miscellaneous

Total Routine Maintenance
Percent of Dose

0.7

14.8

1.5

2.8

2.8

0.8

2.3

8.8

31.7
Fraction

x 450 man-rem

3

67

7

13

13

4

10

40

144

(a) Adapted from Reference 7, Table 6-1 and from Table 2.1-2 of this report.

18,000 man-rem for the 40-year occupational radiation dose per reactor from operation, maintenance, and refueling. It should be noted that the 40-year license granted by the NRC includes time of construction, which can amount to 10 years. The 40-year operational lifetime used here does not include construction and assumes 30 years of actual operation and 10 years of downtime for maintenance and refueling. This is consistent with the assumptions in Reference 3.

It is also necessary to estimate what fraction of a given radiation dose might be saved by various decommissioning alternatives. In the absence of substantial experience, we have assumed a uniform $5 \%$, unless another figure is clearly justified. This number represents the judgment of the authors as being reasonable and conservative. Greater accuracy is not warranted because the decommissioning radiation dose to which the fraction is applied is itself an estimate.

Finally, it should be noted that radiation dose savings are not necessarily cumulative, i.e., the reduction of a given dose by one alternative may pre-empt any reduction of that same dose by another alternative. 


\subsection{COST CALCULATIONS}

Cost estimates for each decommissioning alternative include capital or initial costs, costs to operate and maintain the apparatus during reactor operation and decomissioning, and any cost reductions resulting from the application of the alternative during reactor operation and decommissioning. Capital costs and net costs during decommissioning are estimated from known 1978 labor and material costs, from vendor price 1 ists, from Reference 3 , and from data contained in NUREG-0241. (10) Net costs during operation are estimated using data from the same sources, except that costs for replacement power during reactor downtime are not included.

\subsubsection{Costs of Replacement Power}

If a utility is required to purchase replacement power at wholesale rates from outside its own system during periods of plant maintenance, the costs can be substantial. At one and one-half cents per kjlowatt hour, 24 hours of replacement power for a 1175 -MWe reactor will cost over $\$ 400,000$. Any maintenance technique which reduces plant downtime by just 2 days per year will save over $\$ 30,000,000$ in replacement power over 40 years. This number is sufficiently large to completely bias the cost or cost reduction associated with a decommissioning alternative that saves maintenance time. Therefore, replacement power cost savings are not included in the cost caiculations. It is important to remember, however, that any decommissioning alternative which reduces maintenance time may also result in the saving of replacement power costs to the extent that the decommissioning alternative is completely paid for.

\subsection{SUMMARY OF ALTERNATIVES}

Decomissioning facilitation alternatives are discussed in Sections 3 through 14. Supporting calculations are presented in the appendix. A summary of the alternatives is presented in Table 2.5-1. It can be seen from the table that any decommissioning facilitation alternative which also facilitates maintenance is likely to result in a greater maintenance radiation dose reduction than decommissioning radiation dose reduction. This is because of the greater opportunity for radiation dose reduction in maintenance than in decom- 
TABLE 2.5-1. Summary of Decommissioning Facilitation Alternatives (a)

\begin{tabular}{|c|c|c|c|c|c|c|c|c|}
\hline Description & Capital Cost & $\begin{array}{l}\text { Cost During } \\
\text { Reactor } \\
\text { Operation } \\
\end{array}$ & $\begin{array}{c}\text { Cost During } \\
\text { Decommissioning }\end{array}$ & Total Cost & $\begin{array}{l}\text { Operating } \\
\text { Dose } \\
\text { Reduction } \\
\text { (mun-rem) }\end{array}$ & $\begin{array}{l}\text { Decommis- } \\
\text { sioning Dose } \\
\text { Reduction } \\
\text { (man-ren) } \\
\end{array}$ & $\begin{array}{c}\text { Total } \\
\text { Oose } \\
\text { Reduction } \\
\text { (man-rent) } \\
\end{array}$ & $\begin{array}{l}\text { Unit Cost } \\
\$ / \text { man-rem } \\
\end{array}$ \\
\hline Improved Documentation & 355000 & $\$ 2760000$ & $\$(450000)^{(b)}$ & $\$ 2665000$ & 900 & 54 & 954 & 2800 \\
\hline Improved Access & 367000 & $(16000)$ & $(36000)$ & 315000 & 356 & 15 & 371 & 850 \\
\hline Pressure Vessel Internals & 744000 & -- & $(173000)$ & 571000 & $\ldots$ & 132 & 132 & 4300 \\
\hline \multicolumn{9}{|l|}{ Biological Shield } \\
\hline Holes & 41000 & $\cdots$ & $(18000)$ & 23000 & $-\infty$ & 3 & 3 & 7700 \\
\hline Panels & 1695000 & $\cdots$ & $(250000)$ & 1445000 & $\ldots$ & 12 & 12 & 120000 \\
\hline \multicolumn{9}{|l|}{$\begin{array}{l}\text { Contaminated Concrete } \\
\text { Protection and Removal }\end{array}$} \\
\hline kine & 21022000 & $\cdots$ & (3 340000$)$ & 17682000 & $\cdots$ & 17 & 17 & 1040000 \\
\hline Epoxy & 1692000 & $\cdots$ & $(3340000)$ & $(1648000)$ & $\cdots$ & 17 & 17 & $0^{(c)}$ \\
\hline Embed & 21022000 & $\cdots$ & $\left(\begin{array}{lll}1 & 113 & 000\end{array}\right)$ & 19909000 & --- & 6 & 6 & 3318000 \\
\hline $\begin{array}{l}\text { Special Shielded } \\
\text { Maintenance Shop }\end{array}$ & 168000 & $\left(\begin{array}{lll}418 & 000\end{array}\right)$ & $\left(\begin{array}{ll}187 & 000\end{array}\right)$ & $(437000)$ & 356 & 11 & 367 & 0 \\
\hline \multicolumn{9}{|l|}{ Improved Shielding } \\
\hline Pipe & 480000 & $\cdots$ & $\cdots$ & 480000 & 840 & 22 & 862 & 560 \\
\hline Vehicle & 4800000 & 300000 & 23000 & 5123000 & 900 & 54 & 954 & 5400 \\
\hline Incineration & 2000000 & $\left(\begin{array}{lll}2 & 764 & 000\end{array}\right)$ & $\left(\begin{array}{lll}125 & 000\end{array}\right)$ & (889000) & 50 & 2 & 52 & 0 \\
\hline Electropolishing & 840000 & 500000 & $(598000)$ & 742000 & 640 & 22 & 662 & 1100 \\
\hline Renote Maintenance & 100000 & 500000 & 38000 & 638000 & 800 & 54 & 854 & 750 \\
\hline $\begin{array}{l}\text { Primary Loop } \\
\text { Decontanination }\end{array}$ & -- & -- & $\cdots$ & $\cdots$ & -- & -- & -- & -- \\
\hline $\begin{array}{l}\text { Special Tools } \\
\text { and Techniques }\end{array}$ & $\cdots$ & $\cdots$ & -- & $\cdots$ & $\cdots$ & -- & -- & -- \\
\hline
\end{tabular}

Contaminated Concrete

Protection and Removal

(a) Costs are in 1978 dollars. Costs do not include any savings from not having to purchase replacement power during maintenance outages.

(b) Parentheses mean a cost saving.

(c) 0 means a net cost reduction for that option. 
missioning (Section 2.3). Not included in the table is the cost saving from not having to buy replacement power, if a decommissioning facilitation method aiso facilitates maintenance, as discussed in Section 2.4.1.

The last column of the table shows the cost per man-rem saved for each a] ternative, not including any saved cost of replacement power. On this basis, most methods discussed here appear attractive, with the exception of using panels to construct the biological shield, lining contaminable concrete areas with steel panels, and embedding steel sandwich panels within concrete areas to facilitate spalling. Some alternatives show a net cost reduction as well as a dose reduction. This is not meant to imply that saving more money will result in the saving of more radiation dose.

Finally, it is to be noted that decommissioning facilitation alternatives do not reduce or eliminate radioactivity, but merely make it possible for workers to handle radioactivity at less radiation dose to themselves. 


\section{D IMPROVED OOCUMENTATION}

The only power reactor in the United States to be completely dismantled up to the present time is the 58.2-MWth Elk River reactor, which was dismantled between 1971 and 1974. The last sentence of the final program report ${ }^{(11)}$ reads: "The significant value of having correct as-built drawings and good construction photographs available during reactor dismantling cannot be overemphasized." To this might be added 1) the availability of scale models showing equipment locations, concrete pours, concrete penetrations, and the location of reinforcing steel embedded in the concrete; and 2) the availability of complete photographic and written maintenance records.

Implementation of this alternative would necessarily begin well in advance of reactor construction. The principal advantages of this alternative are the reduced radiation doses in operation and maintenance and in decommissioning that would result from more careful planning of necessary activities.

It is estimated that the occupational radiation dose during operation and maintenance could be reduced by 900 man-rem over the 40-year lifetime of the plant, that the occupational radiation dose during decommissioning could be reduced by 54 man-rem, that the capital costs of implementing this alternative would be $\$ 355,000$, that operational costs would be increased by $\$ 2.76$ million, and that decommissioning costs would be reduced by $\$ 450,000$. There would, of course, be no impact on the reactor structure from exercising these options.

\subsection{DISCUSSION}

Extensive record keeping, reporting, and dose awareness programs are already routine in reactor operation; nevertheless, improvements can be made in existing procedures, and new and useful procedures can be introduced. Possibilities are:

Items Currently in Use But Warranting Improvement

- design and construction histories

- as-built drawings (improved by increased quality assurance emphasis)

- photograph file 
- operating procedure records

- maintenance records

- unusual maintenance technique records

- radiation evaluation program.

Items Not Routineiy Used in Current Practice

- scale model showing high dose rate areas, concrete pours, concrete penetrations, and placement of reinforcing steel

- computerized data

- file of related reactor experience.

Table 3.1-1 sumarizes the foregoing items. Reduced radiation dose would be expected to occur because of the development of better informed and, accordingly, better qualified personnel; and because better information permits better planning, more efficient practices, and more extensive dry runs on mock-ups of equipment located in high dose rate areas.

TABLE 3.1-1. Improved Documentation

\begin{tabular}{|c|c|c|c|c|c|c|c|}
\hline & \multirow[b]{2}{*}{$\begin{array}{r}\text { Current } \\
\text { Practice }\end{array}$} & \multirow[b]{2}{*}{$\begin{array}{l}\text { Initiate } \\
\text { or improve }\end{array}$} & \multirow[b]{2}{*}{$\begin{array}{c}\text { One Time (OT) } \\
\text { Continuing (CT) }\end{array}$} & \multirow[b]{2}{*}{$\begin{array}{c}\text { Additional } \\
\text { Capital Cost } \\
\text { (\$ thousands }) \\
\end{array}$} & \multirow{2}{*}{$\begin{array}{c}\text { Additional } \\
\text { Annual } \\
\text { Operating Cost } \\
\text { is thousands) }\end{array}$} & \multicolumn{2}{|c|}{$\begin{array}{c}\text { Economic Benefits } \\
\text { Annual }\end{array}$} \\
\hline & & & & & & $\begin{array}{c}\text { Annuat } \\
\text { Operating } \\
\text { is thousands) }\end{array}$ & $\begin{array}{l}\text { Decommissioning } \\
\text { (\$ thousands) }\end{array}$ \\
\hline $\begin{array}{l}\text { Design/Construction } \\
\text { Histories }\end{array}$ & Minima? & Yes & OT & 20 & $\ldots$ & 1 & $t$ \\
\hline Up-to-Date As-Buil ts & Minima 1 & Yes & $\mathrm{CT}$ & 100 & 8 & & \\
\hline Photo File & Minimal & Yes & CT & 10 & 15 & & \\
\hline Scale madel & No & Yes & CT & $150^{(a)}$ & 10 & & \\
\hline $\begin{array}{l}\text { Operating Procedure } \\
\text { Update }\end{array}$ & Yes & yes & CT & $\cdots$ & 2 & & \\
\hline $\begin{array}{l}\text { Ma intenance Records } \\
\text { Upda te }\end{array}$ & Minimal & Yes & CT & $\cdots$ & 6 & & \\
\hline $\begin{array}{l}\text { Unusual Ma intenance } \\
\text { Design/Techniques }\end{array}$ & Min ima l & Yes & CT & -- & 10 & & \\
\hline $\begin{array}{l}\text { Files of Reiated } \\
\text { Reactor Experience }\end{array}$ & No & Yes & CT & $\cdots$ & 3 & & \\
\hline $\begin{array}{l}\text { Computerization of } \\
\text { Documented Dara }\end{array}$ & No & Yes & CT & $50^{(b)}$ & 15 & & \\
\hline $\begin{array}{l}\text { Radiation Evaluation } \\
\text { Program }\end{array}$ & Minima 1 & Yes & $C T$ & 25 & 60 & $I$ & $\therefore$ \\
\hline Totals & & & & 355 & 129 & 60 & 450 \\
\hline
\end{tabular}

(a) Scale model total estimated at $\$ 250,000$ a amount shown is allocation to operation and decommissioning.

(b) Anount shown for computer arrived at in consultation with PNL Library personnel. 
Specific benefits would be realized during maintenance through shorter outages, less radiation dose, and greater efficiency (possibly the option of using smaller maintenance teams or of keeping some members of the team out of the high radiation field until their particular essential skill is needed). In decomissioning, like benefits would be realized along with improved overall planning, better public relations, and possibly expedited licensing approvals. In the case of safe storage followed by deferred dismantlement, detailed records are vital because the operating staff will no longer be available for consultation.

Adequate as-built drawings form the cornerstone of good plant operating maintenance. As a means of assuring adequate attention to as-built drawings, greater procedural emphasis on quality assurance during the design and construction period is vital and should be extended to the as-built stage as a tool to improve the recorded design and construction information.

of the other items currently in use but warranting further emphasis, the strengthening of the radiation evaluation program (REP) can achieve the most results. The REP would receive data from computer outputs in the home plant, as well as other operating plants, and would provide emphasis on areas showing the greatest need and/or potential for dose reduction. The existing exposure reduction organization (perhaps a single individual), which presently is assigned the responsibility of recommending dose reduction programs, would manage the REP and be responsible to top management in making recommendations and in assuring the performance of steps necessary to accompitish the reduction in radiation dose.

The scale model is the most expensive capital item connected with this alternative. The assistance that this feature can provide, however, should be substantial by offering better task visualization, clearance identification, movement constraints, and general operating logistics.

In computerizing the documented data, there is further assurance that an operation can be adequately researched in advance. The supervisory personnel would avoid literature searches to uncover methods or techniques not already 
in use at the same plant. The program visualized here is a modest but adequate tool that is not constantly on iine, operates in batch mode, employs established programs (purchasable), and is not expensive to maintain with current data after it is set up. By means of this system, a file of applicable experiences from elsewhere in the industry could be generated, maintained, and made available for both preventive maintenance and preplanning of correction techniques. Capital and annual costs to computerize data are shown in Tabie 3.1-1.

The evaluation of the above jtems is difficult because of the lack of adequate data. It is obvious, however, that if a better informed worker is given the opportunity to more adequately visualize and dry-run an expected task, he will turn in an improved performance.

\subsection{COST AND DOSE ESTIMATES}

Estimates of the costs and radiation dose reductions resulting from implementing an improved documentation program are presented below.

\section{Capital Costs}

Capital costs are estimated to be $\$ 355,000$ (Table 3.1-1). This amount represents additional capital expenditures on items already included in the reactor program and capital expenditures on new jtems. Individual items include improved design and construction histories $(\$ 20,000)$, as-built drawings $(\$ 100,000)$, and photo files $(\$ 10,000)$ for recording maintenance operations. Essentially "new" items recommended are a scale model $(\$ 150,000)$; the setting up of a radiation evaluation program, with the sole function of reducing exposure (for which an administrative organization expense of $\$ 25,000$ has been estimated); and computerization of all data for exposure reduction purposes on a modest basis $(\$ 50,000)$ to speed information retrieval and awareness.

The scale model estimated cost was arrived at through consultation with Pacific Northwest Laboratory (PNL) modeling personne?. An elaborate unit was recently procured by Washington Public Power Supply System (WPPSS) for a cost in the range of $\$ 250,000$ to $\$ 500,000$. The scale model cost for this study is 
estimated at $\$ 250,000$. However, since the model would also be used for public reactions, total staff orientation and other purposes, only $\$ 150,000$ of this amount is allocated to improved documentation.

Whether the establishment $(\$ 25,000)$ and operation of a radiation evaluation program qualifies under the heading of improved documentation is questionable. However, the enforcement of a dose awareness program through dissemination of related information--and inclusion of a dose coordination function--does qualify this item for inclusion here. NRC Regulatory Guide 8.8 addresses the broad function of dose reduction via a strong plant awareness program as is proposed here.

Costs During Reactor Operation

The annual operating cost includes the cost to keep up to date with an increasing volume of information. White this expense represents partial manpower charges, it does include the full allowance for the REP. The total additional annual operating cost is estimated to be $\$ 129,000$ per year (Table 3.1-1), or $\$ 5.16$ million over 40 years. The assumption that better planning will reduce routine reactor downtime of 91 days per year by $5 \%$, or 5 days, leads to an annual saving of $\$ 60,000$ (220 full-time employees at $\$ 20,000$ per year) in reactor maintenance costs, or $\$ 2.40$ million in 40 years.

The net operating cost to implement an improved documentation program over 50 years is $\$ 2.76$ million.

\section{Costs During Decomissioning}

The assumptions of a cost of $\$ 9$ million for decommissioning labor and a $5 \%$ savings through improved documentation leads to a net decomissioning cost saving of $\$ 450,000$.

Dose Reduction During Reactor Operation

The assumptions of a total maintenance radiation dose of 18,000 man-rem and a $5 \%$ reduction over 40 years, leads to a net maintenance dose reduction of 900 man-rem as a result of improved documentation. 
Dose Reduction During Decommissioning

The assumption of a total decommissioning occupational radiation dose of 1083 man-rem and a 5\% dose reduction because of improved documentation leads to a decommissioning dose reduction of 54 man-rem. 


\subsection{IMPROVED ACCESS TO CONTAMINATED EQUIPMENT}

Access to contaminated equipment could be improved by the installation of removable roof and wall panels. This would simplify removal of contaminated equipment for maintenance, replacement, and disposal during decormissioning. Candidate items of equipment include the pressurizer and steam generators in a PWR containment building, and contaminated tanks, ion exchangers, and filters in the auxiliary and fuel buildings of a PWR or BWR. Newer reactors already include some of these panels.

Implementation of this alternative would begin in the design phase and continue through construction. The principal advantages are reduced radiation doses during maintenance and decommissioning, because of quicker and easier access to contaminated equipment and quicker and easier means of removing the equipment.

It is estimated that the occupational radiation dose accumulated during maintenance could be reduced by 356 man-rem and that the occupational radiation dose during decommissioning could be reduced by 15 man-rem. For a capital cost of $\$ 367,000$, it is estimated that operating costs could be reduced by $\$ 16,000$ and that decommissioning costs could be reduced by $\$ 36,000$. The capital costs would necessarily include the costs of careful design and construction in order to avoid impacting the structural integrity of the buildings. It is to be expected that bearing walls and load bearing floors would be involved.

\subsection{DISCUSSION}

Removal of large contaminated equipment to areas where low background radiation permits increased residence time during maintenance is a desirable way to reduce dose to personnel. This is also true during decommissioning. Increased accessibility also reduces manpower requirements during these two phases.

Improved access is achievable by providing removable roofs and knockouttype walls in the buildings that house major equipment requiring periodic maintenance. This equipment includes the pressurizer in the reactor containment 
building, fuel handling equipment in the fuel building, and radwaste equipment in the auxiliary building. The modifications consist of precast covers, generally 24 in. thick or more, for roof access, and walls of masonry block protected by 2 -in. metal plates. All openings are assumed to be large enough to remove entire pieces of equjpment and will require additional structural support.

Pressurizer access is valuable from an operating standpoint, as well as decomissioning, since it is anticipated that replacement of internal components (heaters, etc.) and, if required, the entire pressurizer, would benefit by overhead access.

Auxiliary and fuel building access would be expected to provide similar benefits in reduced dose. Capital cost would be fairly large for the dose benefit, since the improved access involves many pieces of equipment individwaily enclosed.

\subsection{COST AND DOSE ESTIMATES}

Estimates of the costs and radiation dose reductions resulting from implementing an improved access program are presented below.

\section{Capita] Costs}

Capital costs of the buildings will be increased because of the requirements for greater building volumes and structural stiffening adjacent to the removable sections.

Pressurizer:

Precast roof pane]: $330 \mathrm{ft}^{2}$ a $\$ 120 / \mathrm{ft}^{2}$

$$
\left(\sim 25 \mathrm{yd}^{3}\right) \quad \$ 40,000
$$

Fuel and Auxiliary Buildings:

Walls: $3,200 \mathrm{ft}^{2}$ a $\$ 80 / \mathrm{ft}^{2}$ Roof panels: $375 \mathrm{ft}^{2} @ \$ 120 / \mathrm{ft}^{2}\left(\sim 30 \mathrm{yd}^{3}\right) \quad 45,000$ Reinforcing concrete structural increase: $20 \mathrm{yd}^{3}$ a $\$ 1000 / \mathrm{yd}^{3}$ ) Added building volume, $600 \mathrm{ft}^{3}$ a $\$ 10 / \mathrm{ft}^{3}$ 20,000

Total capital costs 
Costs During Reactor Operation (a)

Labor costs during the operational life of the plant will be reduced because of the improved access for repair and/or maintenance. It is estimated that one changeout of pressurizer components during the lifetime of the plant will cost $\$ 64,000(98,0001 \mathrm{~b} @ \$ 0.65 / 1 \mathrm{~b})$ and that changeout of equipment in the auxiliary and fuel buildings during the life of the reactor will cost $\$ 252,000(388,000$ lb $(0.65 / 1 b)$. A $5 \%$ reduction of these costs by improved access will result in a maintenance cost saving of $\$ 16,000$ over the 40 -year operating lifetime of the plant.

Costs During Decommissioning

Decommissioning labor costs will be reduced because of improved access; however, there may be an increase in the volume of material to be buried because of the increased volume of the building.

The decommissioning cost of the pressurizer is estimated at $\$ 0.65 / 1 \mathrm{~b}$ for $195,000 \mathrm{lb}$, or $\$ 127,000$. A $5 \%$ cost saving is $\$ 6000$. The cost reduction because of concrete demolition that is avoided by having access hatches is $\$ 1500\left(25 \mathrm{yd}^{3}\right.$ @ $\left.\$ 60 / y \mathrm{~d}^{3}\right)$.

The cost of removal of major components in the auxiliary and fuel buildings is estimated at $\$ 0.65 / 1 \mathrm{~b}$ for $775,0001 \mathrm{~b}$, or $\$ 504,000$. A $5 \%$ cost saving is $\$ 25,000$. The cost reduction of concrete demolition avoided is $\$ 3000$ (50 $\mathrm{yd}^{3}$ $\left.x \$ 60 / y d^{3}\right)$.

The total decommissioning cost saving resulting from improved access is estimated to be $\$ 36,000$.

Dose Reduction During Reactor Operation

The annual special maintenance radiation dose is 178 man-rem (Table 2.3-1). While this is given as an annual dose, it presumably refers to non-recurring doses and thus is large in some years for a given reactor and small in other years for the same reactor. A $5 \%$ reduction in special maintenance radiation dose because of improved access, accumulated over 40 years, is 356 man-rem.

(a) See Appendix A, Note 1 . 
Dose Reduction During Decomissioning

The estimated radiation dose to renove the pressurizer is 50.7 man-rem (Table 2.1-1). A $5 \%$ dose reduction because of improved access is 3 man-rem.

The estimated radiation dose to remove special equipment in the auxiliary and fuel buildings (Table 2.1-1) is 231.7 man-ren (tanks, pumps, heat exchangers, CVC system, condensate tank holding system, and boric acid system tanks and piping). A $5 \%$ dose reduction is 12 man-rem.

The total decommissioning dose reduction because of improved access is estimated to be 15 man-rem. 


\subsection{SUBSTITUTION OF MATERIALS IN THE PRESSURE VESSEL INTERNALS}

Immediate dismantlement and disposal of the activated internals of the reference PWR pressure vessel will resuit in an estimated occupational radiation dose of 86.5 man-rem, in spite of the use of remote or water-shielded disassembiy techniques (Table 2.1-1). This dose comes mainly from ${ }^{60} \mathrm{Co}_{0}$, which is a neutron activation product of the $100 \%$ abundant ${ }^{59} C_{0}$ present in the stainless steels used in reactor internals. Decontamination techniques are of no value because the activated nuclides are not surface contaminants, but rather part of the steel alloy itself. Opportunities for reducing radiation dose from this source include improving remote or underwater dismantling and reducing the amount of material, specifically ${ }^{59} \mathrm{Co}$, which is subject to activation.

Reducing the amount of ${ }^{59} \mathrm{Co}$ would have to be carried out at the reactor pressure vessel design stage. The principal advantages of this alternative are to reduce radiation dose during decomissioning and to lessen or obviate the importance of ${ }^{60}$ Co as a consideration in the length of safe storage, if safe storage followed by deferred dismantlement has been chosen as the mode of decormissioning.

Substitution of alloys such as Zircaloy for stainless steel in some of the components of the pressure vesse? internals would reduce ${ }^{60}$ Co activation and subsequent radiation dose to decommissioning personnel and to the public by 132 man-rem, at an increased capital cost of $\$ 744,000$ and a decreased decommissioning cost of $\$ 173,000$. Careful attention would need to be paid, however, to the neutron physics of the reactor before this alternative could be implemented. These calculations are beyond the scope of this study.

\subsection{DISCUSSION}

Replacement of key portions of the stainless steel pressure vessel internals with another alloy such as Zircaloy could lead to a reduced decommissioning radiation dose because of reduced activation of the Zircaloy. Measurements made during the dismantlement of the Elk River Reactor (12) showed a maximum contact radiation dose rate of $2800 \mathrm{R} /$ hour in an upper shroud assembly of stainless steel, while a lower shroud assembly of Zircaloy showed a radiation 
dose rate of $175 \mathrm{R} /$ hour, more than an order of magnitude less in a similar neutron flux environment. The reference reactor internals utilize 304 stainless steel as a major material, thus making the el imination of ${ }^{59}$ Co (which becomes activated to form ${ }^{60} \mathrm{Co}$ ) an attractive possibility. The reactor internals involve 400,000 $1 \mathrm{~b}^{(\mathrm{a})}$ of stainless steel, 4,800,000 Ci of activation, and a dismantling cost of $\$ 1,500,000$. The shroud itself weighs $27,0001 \mathrm{~b}$ and contains $3,400,000 \mathrm{Ci}$, or over $70 \%$ of the radioactivity associated with the pressure vessel internals. Use of Zircaloy instead of stainless steel in the shroud would be expected to reduce radiation dose from dismantlement and transport of the shroud by $90 \%$. It must be noted, however, that use of Zircaloy in the shroud might allow other pressure vessel components and the pressure vessel wall to become more. highly activated, and thus negate the advantages of Zircaloy in the shroud. It is possible that stainless steel was selected for the shroud material in the reference reactor for neutron absorption in order to reduce pressure vessel embrittlement. A detailed core analysis that would resolve this concern is beyond the scope of this study. It is also possible that stainless steel was selected for economic reasons. Finished Zircaloy components cost approximately $\$ 40 /$ finished $1 b,(b)$ while stainless steel components cost approximately $\$ 5 /$ finished $1 \mathrm{~b}$. (c)

\subsection{COST AND DOSE ESTIMATES}

Estimates of the costs and radiation dose reductions resulting from substituting Zircaloy for stainless steel in the pressure vessel shroud are presented below. In the calculations, no allowance is made for the higher activation of other components.

Capital Costs $(d)$

At a difference in finished cost of $\$ 35 / 1 \mathrm{~b}$, the $27,100-1 \mathrm{~b}$ shroud would add $\$ 950,000$ in capital cost if it were made of Zircaloy rather than stainless
(a) See Appendix A, Note 2.
(b) From Teledyne-Wah Chang.
(c) From Babcock and Wilcox, Co.
(d) See Appendix A, Note 2 . 
steel. Allowing for the difference in specific gravity between Zircaloy (6.29) and stainless steel (8.02) would reduce this cost to $\$ 744,000$.

\section{Costs Ouring Reactor Operation}

There are no costs during reactor operation associated with replacing the stainless steel shroud with a Zircaloy shroud.

Costs During Decommissioning

Of the estimated $\$ 246,000$ cost to dispose of the shroud, $\$ 192,000$ is because of curie surcharges. (a) Reducing the number of curies by an order of magnitude (90\%) will reduce the curie surcharges by $\$ 172,800$, which is the cost saving during decommissioning.

Dose Reduction During Reactor Operation

There is no radiation dose reduction during reactor operation associated with replacing the stainless steel shroud with a Zircaloy shroud. Dose Reduction During Decommissioning

Seventy percent of the estimated 86.5 man-rem dose from dismantiing the reactor internais comes from dismantling the shroud. A $90 \%$ reduction of this dose is 55 man-rem.

of the total radioactivity $(4,844,000 \mathrm{C} i)$ shipped to burial, 3,431,000 $\mathrm{Ci}$, or $71 \%$, is from the shroud alone. A $90 \%$ reduction in the shroud material radioactivity wi11 result in a radiation dose reduction of $64 \%$ to transportation workers and to the public during transportation, or a reduction in estimated radiation dose to transportation workers of 64 man-rem and to the public of 13 man-rem.

The total radiation dose reduction during decomissioning is estimated to be 132 man-rem due to replacing the stainless stee1 shroud with a Zircaloy shroud. This estimate does not allow for possible activation of other components.

(a) Appendix A, Note 2. 



\subsection{DESIGN OF THE BIOLOGICAL SHIELD FOR EASY REMOVAL}

The biological shield is a concrete structure surrounding the reactor pressure vessel. Its purpose is to provide shielding in the containment building and, in the case of PWRs, provide support for the reactor pressure vessel. Two possible alternatives for improving the safety of removing the biological shield are: 1) elimination of the necessity of drilling blasting holes under high dose rate conditions at the time of dismantlement by designing them into the biological shield during construction, and 2) elimination of the blasting process altogether by installing a modular biological shield that can be disassembled using remote cranes.

Implementation of these alternatives would begin at the design stage and continue through the construction stage. The advantage is reduced radiation dose during decommissioning.

It is estimated that the first alternative would increase capital costs by $\$ 41,000$, would reduce decommissioning costs by $\$ 18,000$, and would reduce occupational radiation dose during decommissioning by 3 man-rem. It is estimated that the second alternative would increase capital costs by $\$ 1,695,000$, would reduce decommissioning costs by $\$ 250,000$, and would reduce occupational radiation dose by 12 man-rem. The latter al ternative would, of course, have a major impact on the structure of the biological shield, which would have to be taken into account during facility design.

\subsection{DISCUSSION}

Blasting has been used in the past as the primary method for removal of activated concrete in the biological shield. Holes are drilled remotely and are packed with explosives, blasting mats are used to protect the containment building, and dust control is accomplished by fog spraying prior to and after each blast. Dismantling begins at the top inside circumference of the shield and break-up is carried outward at each level before beginning the series again at the next lower level. The charges are carefully controlled to preclude pressure surges that might damage the ventilation system's integrity. Vertical holes are drilled to break out a ring of concrete at the inner 
circumference to a vertical depth of about $5 \mathrm{ft}$ for each level. The subsequent detonations continue radially outward until all of the activated concrete is removed at that level before the process is repeated at the next lower level.

Preplacement of the vertical holes during construction would eliminate the costs of post-drilling by remote means. Biological shield thickness could be maintained by filling the holes with sand prior to pouring each succeeding vertical lift.

Design of the biological shield as a series of modularized components may be reasonably accomplished in a BWR, where the shield serves only the function of personnel shielding. In a PWR, the biological shield also supports the reactor vessel and must be designed primarily for this purpose, with its secondary function being to provide sufficient shielding thickness. A conceptual design of the biological shield is presented in Figure 6.1-1. The support structure consists of a frame of heavy I-beams designed to support the reactor

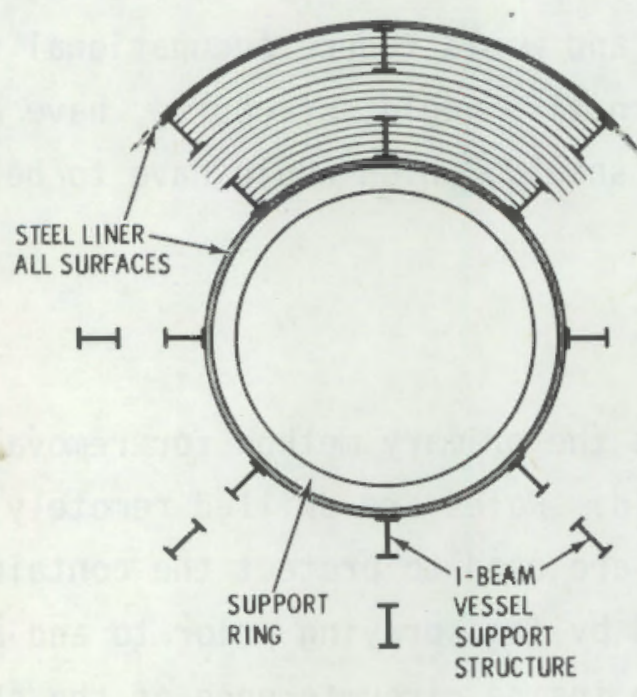

PLAN VIEW

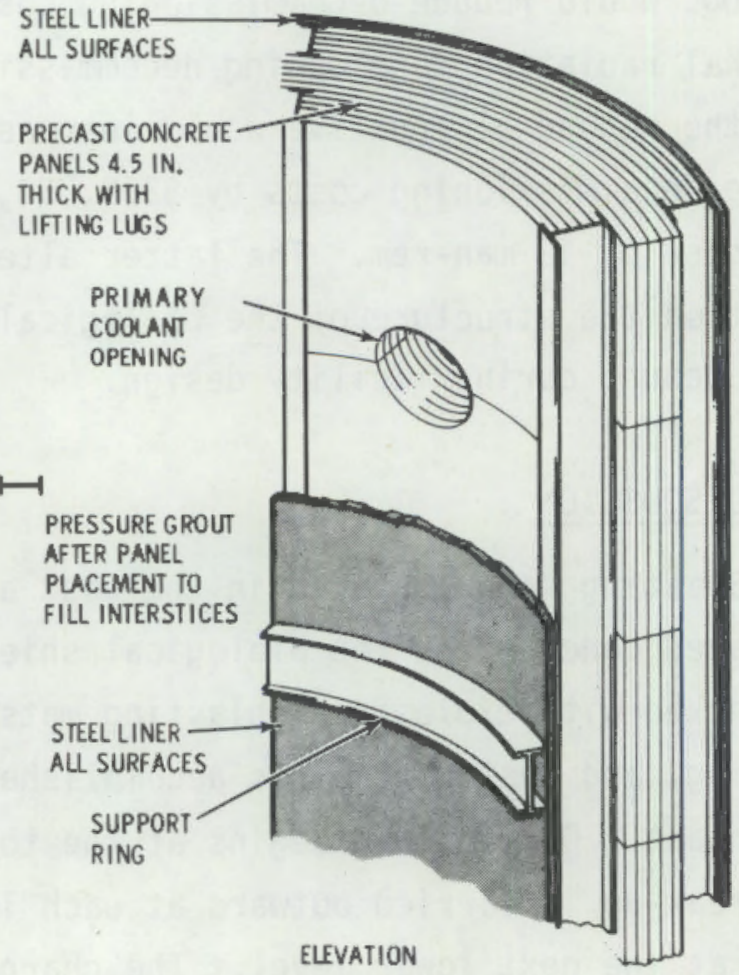

ELFVATION

FIGURE 6.1-1. Conceptual Design of Biological Shield 
and provide a receptacle for precast concrete panels, which are inserted and pressure grouted in place after insertion. The biological shield would be made of 16 layers of preformed concrete in onion-like layers held in place by structural steel I-beams. Removal of the panels is accomplished by remote crane operation, which would exert enough lifting force to fracture the grout, allowing each panel to be put into proper containers for shipping.

Activation of the steel I-beams used to support the pressure vessel and to hold together the 16 layers of precast concrete would not be a problem because the carbon steel used for structural support and reinforcement contains very little ${ }^{59}$ Co to become activated to ${ }^{60} \mathrm{Co}$.

A modular design of the biological shield might also expedite removal of the reactor pressure vessel should that become necessary during the life of the reactor. Careful attention would need to be paid to the structural design of the biological shield.

\subsection{COST AND DOSE ESTIMATES FOR CASE I: PREPLACING BLASTING HOLES IN THE BIOLOGICAL SHIELD}

Estimates of the costs and radiation dose reductions resulting from preplacing blasting holes in the biological shield are presented below.

\section{Capital Costs}

The capital cost of preplacing blasting holes is estimated to be $5 \%$ of the capital cost of the biological shield, or $\$ 41,000$. (a)

\section{Costs During Reactor Operation}

There would be no costs during reactor operation from preplacing blasting holes in the biological shield.

Costs During Decommissioning

The difference in cost between dismantling the activated portion of a predrilled biological shield and one that is not predrilled is the difference in cost between uncapping and removing sand from the holes and drilling the holes. This cost saving is estimated to be $\$ 18,000$. (a)

(a) Appendix A, Note 3 . 


\section{Dose Reduction During Reactor Operation}

There would be no radiation dose or dose reduction during reactor operation associated with preplaced blasting holes in the biological shield.

\section{Dose Reduction During Decomissioning}

The dose reduction in decommissioning is the difference between the dose received from driling the blasting holes and the dose received from uncapping and cleaning predrilled blasting holes. If this difference is $5 \%$ of the total dose of 61.6 man-rem (Table 2.1-1) necessary to remove contaminated internat structures, then the dose saving would be 3 man-rem.

\subsection{COST AND DOSE ESTIMATES FDR CASE II: MODULAR DESIGN OF THE BIOLDGICAL. SHIELD}

Estimated costs and radiation dose reductions resulting from modular design of the biological shield are presented below.

\section{Capital Cost}

The capital cost of modular design of the biological shield is the difference in construction cost of a modular biological shieid and a standard biological shield. Precast concrete panels, a structural steel frame, and steel plate liners are estimated to cost $\$ 2,506,000$, while the cost of a standard concrete design is $\$ 811,000$, for a difference of $\$ 1,695,000$. (a)

Costs During Reactor Operation

There would be no costs during reactor operation associated with a modular design of the biological shield.

\section{Costs During Decommissioning}

The labor cost reduction in demolition of a modular bioiogical shield is estimated to be 2500 man-days at $\$ 100 /$ man-day, or $\$ 250,000$. Dose Reduction During Reactor Operation

There would be no radiation dose reduction during reactor operation from modular design of the biological shield.

(a) Appendix A, Note 3. 
Dose Reduction During Decommissioning

Removal of modularized panels by remote crane operation would el iminate the drilling and packing of explosives, and simplify the pickup of debris, since the panels would be in a form that could be packaged as a unit. It is estimated that the dose reduction would be at least four times the dose reduction achieved by predrilling blasting holes, or 12 man-rem. This is because all of the dose from drilling, as well as some of the dose from handling the concrete rubble, would be saved. 
•

.

, 


\subsection{TECHNIQUES FOR IMPROVED PROTECTION OF CONCRETE AND IMPROVED REMOVAL OF CONTAMINATED CONCRETE}

Contamination of concrete structural surfaces occurs during the lifetime of a nuclear plant because of spills, seepage, equipment leaks, and operational flooding of pits. The depth of contamination of an unlined surface requires that about $6 \mathrm{in}$. of exposed concrete be spalled out and disposed of by burial. Stainless steel lined surfaces that are flooded may still require spalling of the concrete underneath, but usually to a depth of less than 4 in. to remove the contaminated concrete. Large areas are involved. Therefore, large masses of concrete must be removed, packaged, and sent to disposal sites.

The magnitude of the problem can be reduced by protecting the concrete surfaces from contamination or by improving the methods used to remove concrete. Three alternatives are discussed here. The first is to protect all contaminable, but nonsubmerged concrete surfaces with carbon steel liners. This would require some $356,000 \mathrm{ft}^{2}$ of 1 iner plate at an installed cost of $\$ 21,022,000$. The cost saving from reducing the volume of concrete requiring removal and disposal would amount to $\$ 3,340,000$, for a net cost of $\$ 17,682,000$. Radiation dose reduction would amount to 17 man-rem. Care would need to be taken in the design of the facility to assure the structural integrity required to support the weight of the liner.

The second alternative is to protect these same surfaces with epoxy or phenolic coatings. If the coating could be maintained intact throughout the operating lifetime of the plant, then any contamination could be readily washed off. The area requiring protection is the same as in the first option. The cost, however, would be much less, approximately $\$ 1,692,000$. The cost savings from reducing the volume of contaminated concrete would also be the same as for the first option, for a net cost reduction of $\$ 1,648,000$. The calculated 17 man-rem radiation dose reduction would thus be at no net cost.

The third alternative would eliminate drilling and simplify spalling by installing a carbon steel sandwich inside of potentially contaminable (but nonsubmerged) floors and walls at a depth of $4 \mathrm{in.}$ Air or liquid pressure applied between the plates would provide the spalling force. The cost to 
embed such plates would be $\$ 21,022,000$, and the cost savings from reduced drilling and concrete disposal would be $\$ 1,113,000$, for a net cost of $\$ 19,909,000$. A radiation dose saving of 6 man-rem is estimated. Again, careful attention would need to be paid to structural design.

Planning of these alternatives would begin at the reactor design stage, and implementation would be carried out during construction.

\subsection{DISCUSSION}

Concrete surfaces contaminated during reactor operation (as distinguished from activated) present a serious problem during decomissioning, primarily because of the massive areas involved. These areas generate large volumes of concrete that must be removed, transported, and buried at substantial costs in dollars and in radiation dose.

The problem can be reduced by either of two methods: 1) protection of the concrete surfaces to el iminate or reduce the contaminated volume, or 2) improvement in the methods of removing concrete. Three cases that deat with these two methods are discussed here. Case I utilizes the protection of nearly al1 nonsubmerged surfaces susceptible to contamination with carbon steel liners. Case II utilizes the protection of these same surfaces with a chemical coating of epoxy. Case III introduces a remote method of spalling concrete that reduces the cost and radiation dose presently encountered in the decommissioing cycle.

Implementation of Case I would require the addition of $356,300 \mathrm{ft}^{2}$ of carbon. steel liner plate to unprotected contaminable areas in buildings other than the containment building. (a)

Implementation of Case II would require the application of epoxy coatings to the same area as in Case $I$.

Implementation of Case III, which is essentialiy a new method, would require embedding $356,000 \mathrm{ft}^{2}$ of carbon steel sandwich plate into the floors and walls at a depth of 4 in. from the surface. The steel plates would be

(a) Appendix A, Note 4 . 
anchored into the reinforced wall or floor and would contain conduits through which pressure, ejther pneumatic or liquid, could be applied between the plates to force the upper plate upwards and provide the spalling force remotely. The depth of embedment will also reduce the amount of concrete to be disposed of from 6 to 4 in.

Other methods of spalling concrete, not considered here, include the following:

- Heat by electric current application to rebar. Unknowns include current requirements, safety requirements, and costs.

- Microwave heating of the concrete. Unknowns include feasibility, electrical requirements, and costs.

- Preformed expansion holes. The installation of preformed expansion holes perpendicular to the wall surface at $1-\mathrm{ft}$ increments may be feasible in walls where risk of contamination of the inner surfaces through leakage is minimal. Installation in floors is not considered feasible from this standpoint, since it would require further drilling below the spalling to remove additional material.

7.2 COST AND DOSE ESTIMATES FOR CASE I: CARBON STEEL LINERS

Estimates of the costs and radiation dose reductions resulting from installing carbon steel liners are presented below.

\section{Capital Costs}

The capital cost of installing $356,300 \mathrm{ft}^{2}$ of carbon steel liners on concrete is approximately $\$ 21,022,000$, based on an installed cost of $\$ 59 / \mathrm{ft}^{2}$. (a) Costs During Reactor Operation

There would be little cost advantage during reactor operation related to the 1 ining of nonsubmerged concrete. Although cleanup of radioactive spilis might be easier, the cost per spill probably would not change.

(a) Appendix A, Note 4 . 


\section{Costs Ouring Decommissioning}

Costs are saved during decommissioning by reducing the volume of contaminated concrete and thus avoiding its subsequent removal and disposal. The $356,300 \mathrm{ft}^{2}$ of 1 ined, nonsubmerged concrete would, if not protected, require 2,623 man-days at $\$ 100 /$ man-day, or $\$ 262,000$, to remove by spallation. (a) The resulting 25,654,000 lb of concrete rubble would cost 12 cents/ib, or $\$ 3,078,000$, to dispose of. (a) The net decommissioning saving would be $\$ 3,340,000$. It is assumed that all operational spills of radioactive material have been cleaned up and that the carbon steel liners are themselves uncontaminated and do not require removal during decommissioning. If this is not the case, then an already expensive option is made more expensive by the requirement to dismantle, package, and dispose of contaminated steel.

Dose Reduction During Reactor Operation

Because of the ease in cleaning up radioactive spills, some dose reduction might occur during reactor operation. This dose reduction was not calculated. Dose Reduction During Decommissioning

The $25,654,000$ lb of concrete that would not have to be removed is $86 \%$ of the total of $29,732,000 \mathrm{lb}$ of concrete that would otherwise be removed in the case of immediate dismantlement (Reference 3, Tables 6.4-4 and 6.4-5). The two entries in Table 2.1-1 referring to contaminated structures or contaminated concrete total 68.2 man-rem. Of this total, probably only one-quarter, or 17.1 man-rem, involve concrete. The decommissioning dose reduction is estimated to be $86 \%$ of 17.1 man-rem, or 15 man-rem. A transportation radiation dose reduction in the same proportion is 2 man-rem. The overall dose reduction from installing carbon steel liners is 17 man-rem.

\subsection{COST ANO DOSE ESTIMATES FOR CASE II: EPOXY COATINGS}

Estimates of the costs and radiation dose reductions resulting from protecting concrete surfaces with epoxy coatings are presented below.

(a) Appendix A, Note 4. 


\section{Capital Costs}

Research in the area of protective coatings for both concrete and carbon steel liner plates has resulted in the development of epoxys. These coatings provide a more durable surface than concrete and provide corrosion inhibition for carbon stee1. The epoxy treatment has been estimated by United Engineers \& Constructors at $\$ 4.50$ to $\$ 5.00 / \mathrm{ft}^{2}$ (13) At $\$ 4.75 / \mathrm{ft}^{2}, 356,300 \mathrm{ft}^{2}$ of coating would cost $\$ 1,692,400$.

Costs During Reactor Operation

Epoxy lining of concrete would not be expected to change operating costs much, except that the lining would make cleanup of radioactive spills easier. Costs During Deconmissioning

Decommissioning costs would be reduced the same amount as in Case I, namely $\$ 3,340,000$ for the elimination of spalling and disposal of $25,654,000$ ib of concrete.

Dose Reduction Ouring Reactor Operation

A slight dose reduction might accrue during reactor operation due to ease in cleaning up radioactive spills. This dose was not calculated. Dose Reduction During Decomissioning

The dose reduction during decommissioning from protecting concrete surfaces with epoxy coatings would be the same as in Case I, namely 17 man-rem.

\subsection{COST AND DOSE ESTIMATES FOR CASE III: EMBED STEEL PLATE}

Estimates of the costs and radiation dose reductions resulting from installing carbon steel expansion plates are presented below.

Capital Costs

The capital cost of fabrication and installation of carbon steel expansion plates is estimated to be approximately $\$ 59 / \mathrm{ft}^{2}$. (a) In a reference nuclear plant containing $356,300 \mathrm{ft}^{2}$ of unprotected area, the cost to install expansion plates would amount to $\$ 21,022,000$.

(a) Appendix A, Note 4 . 


\section{Costs During Reactor Operation}

There would be no cost or cost saving during reactor operation.

Costs During Decommissioning

Fracture plate spalling of the top 4 in. of concrete would reduce the amount of concrete to be removed and disposed of by one-third. On the assumption that the labor required to prepare for and carry out hydraulic or pneumatic fracture is equivalent to the labor to drill holes, a labor saving of one-third of $\$ 262,000$, or $\$ 87,000$ will result. (a) A similar saving in the amount of concrete requiring disposal will result in a cost saving of $\$ 1,026,000$, or a net saving of $\$ 1,113,000$. Again, it is assumed that the stee] is not contaminated, which may not be the case.

Dose Reduction During Reactor Operation

There would be no radiation dose reduction during operation.

Dose Reduction During Decommissioning

The radiation dose reduction during decommissioning due to the installation of carbon steel expansion plates would be expected to be one-third of the radiation dose reduction in Case $I$, because one-third of the concrete would not need to be removed. One-third of 17 man-rem is 6 man-rem.

(a) Appendix A, Note 4. 


\subsection{SPECIAL SHIELDED MAINTENANCE SHOP}

Expanding the existing maintenance shop in the fuel building by $50 \%$ and adding special shielding would allow shielded laydown, maintenance, and dismantling of all but the largest pieces of equipment.

Implementation of this alternative would begin at the design stage and continue through construction. The advantages would be reduced occupational radiation dose during maintenance and decomonissioning.

Capital costs of expansion are estimated at $\$ 168,000$, which are offset by a reduction of $\$ 418,000$ in maintenance costs and by a reduction of $\$ 187,000$ during decommissioning. The net cost saving of $\$ 437,000$ is also estimated to save 356 man-rem of occupational radiation dose during operation and 11 man-rem of occupational radiation dose during decommissioning. The structural integrity of the fuel building would be affected; therefore, a structural redesign would be necessary.

\subsection{DISCUSSION}

The reference reactor facility has an enclosed nuclear equipment maintenance shop about $25 \mathrm{ft}$ by $50 \mathrm{ft}$ on the operating floor level of the fuel building. (a) other than the reactor vessel, the largest units of equipment in the containment building are the four steam generators, which are each $68 \mathrm{ft}$ long and $13 \mathrm{ft}$ in diameter. Servicing one of these units in the planned nuclear equipment maintenance space would require dismantling the unit outside the shop and transporting it to the shop for maintenance. Since the planned 25-ft by 50-ft space may not be clear, it will probably also be necessary to dismantle other pieces of equipment. The pressurizer is over $53 \mathrm{ft}$ long, while the primary pumps and other equipment are in the range of $30 \mathrm{ft}$ long. By expanding the shop space from $25 \mathrm{ft}$ by $50 \mathrm{ft}$ to $25 \mathrm{ft}$ by $80 \mathrm{ft}$, maintenance and decomissioning costs could be saved and dose reduced. This is generally because predismantling outside the shop could be avoided, which would otherwise involve unshielded operations and usually less-efficient equipment than is available in the shop.

(a) Reference 3, Figure A.2-21. 


\subsection{COST AND DOSE ESTIMATES}

Estimates of the costs and radiation dose reductions resulting from the installation of a special shielded maintenance shop are presented below. Capita] Costs

The capital cost of the $630,000-\mathrm{ft}^{3}$ fuel building structure in $1976 \mathrm{dol}-$ lars is $\$ 3,910,232$. (a) Multiplying by 1.2 to account for inflation brings the cost per unit volume in 1978 dollars to $\$ 7.45 / \mathrm{ft}^{3}$. Adding $750 \mathrm{ft}^{2}$ to the existing 1,250 $\mathrm{ft}^{2}$ maintenance shop (30-ft-high) would cost an additional $\$ 168,000$.

Costs During Reactor Operation

Overhauling four 700,000-1b steam generators three times, four 190,000-1b primary pumps two times, and 4,000,000 ib of other miscellaneous equipment (1,000,000 lb several times) over the 40-year life of the plant results in the maintenance of $13,920,000 \mathrm{lb}$ of equipment. At a saving of $\$ 0.03 / 1 \mathrm{~b}$ in maintenance costs, the total saving is $\$ 417,600$. (b)

Costs During Decommissioning

Decommissioning of $775,000 \mathrm{lb}$ of equipment in the fuel and auxiliary buildings and 5,460,000 tb of equipment in the containment building could benefit from a larger shielded maintenance shop. ${ }^{(b)}$ At $\$ 0.03 / 1 b$, a saving of $\$ 187,000$ results. Dose Reduction During Reactor Operation

From Table 2.3-1, the annual special maintenance radiation dose is 178 man-rem. If this refers to the maintenance of $i$ tems such as steam generators and primary pumps, which do not need major maintenence on an annual basis, then a $5 \%$ radiation dose reduction over 40 years is 356 man-rem.

(a) Reference 10, Account №. 217.

(b) Appendix A, Note 5. 
Dose Reduction During Decommissioning

From Table 2.1-1, the radiation dose from dismantling the steam generators (118.1 man-rem), the primary pumps (5.36 man-rem), and the pressurizers (50.7 man-rem) is 222.4 man-rem. A $5 \%$ dose reduction resulting from the installation of a special shielded maintenance shop is 11 man-rem. 



\subsection{IMPROVED SHIELDING FOR MAINTENANCE AND DECOMMISSIONING PERSONNEL}

Direct protection of personnel from radiation through the use of shielding offers the opportunity to reduce radiation dose to maintenance and decommissioning personnel and at the same time to permit maintenance and decommissioning. Two possible alternatives are: 1) pipe shielding to reduce background levels in work spaces, and 2) a self-contained, shielded vehicle with manipulator arms that can perform functions equivalent to remote cell manipulators.

Implementation of these alternatives would begin at the design stage in order to insure that additional space was made availabie to accommodate extra pipe shielding and to accommodate the movement of the shielded vehicle. The advantage of these alternatives is a direct reduction of radiation dose to maintenance and decommissioning workers.

Pipe shielding is estimated to increase capital costs $\$ 480,000$, without affecting maintenance or decommissioning costs. Radiation dose savings of 840 man-rem during maintenance and 22 man-rem during decommissioning could be effected. A self-contained shielded vehicle with manipulators wouid increase capital costs by $\$ 4,800,000$ and maintenance and decommissioning costs by $\$ 300,000$ and $\$ 23,000$, respectively. Maintenance radiation dose would be reduced by 900 man-rem, and decommissioning radiation dose would be reduced by 54 man-rem. Structural modifications would need to be made in order to provide increased space for pipe shielding and for movement of the shielded vehicle.

\subsection{DISCUSSION}

Piping is insulated in power reactors to maintain thermal efficiency in the primary 10op. Lead shielding with an air gap or insulation could be added to provide both thermal and radiation shielding. Background radiation would be reduced at mechanical equipment, valves, and pumps, which require the major portion of maintenance in an operating plant.

Another shielding medium in use today is water. Although primarily used in the handling of spent fuel, water might also be used in routine maintenance and decommissioning. This would require floodable compartments with access 
platforms for maintenance and decommissioning using extended-reach tools. This approach would have limited uses, however, because maintenance requires equipment disassembly, and the equipment would have to be dried after reassembly before it could be used.

Portable shields have been used to provide temporary working areas in highradiation fields. A disadvantage is that a shield in the configuration of a single plane does not provide protection against reflected radiation. A selfcontained, shielded vehicle equipped with manipulator arms could be developed that would permit maintenance and decommissioning activities to proceed in a manner similar to that employed in stationary manipulator-equipped shielded cells. This might require larger access areas with adequate room for maneuverability and enough distance between components requiring maintenance to permit reasonably close approach by the mobile unit, which would be mounted on a tracked vehicle and contain its own life-support system. Fail-safe power units would be required to ensure that the operator(s) could always leave the area.

\subsection{COST AND DOSE ESTIMATES FOR CASE I: PIPE SHIELDING}

Estimates of the costs and dose reductions resulting from installing pipe shielding are presented below.

Capital Costs

Shielding all the primary loop piping, and essentially all radwaste piping, would entail the installation of approximately $60,000 \mathrm{ft}^{2}$ of lead shielding. At a unit price of $\$ 8.00 / \mathrm{ft}^{2}$, the installation costs would be $\$ 480,000$. This assumes use of $1 / 8$-in. lead, which a7ternates 1 MeV gamma rays approximately $18 \%$. These costs do not include redesign and possible strengthening of pipe supports.

Costs During Reactor Operation

There should be no cost to maintain pipe shielding during operation of the reactor. 
Costs During Decommissioning

It is assumed that costs to remove the lead shielding during decommissioning are offset by cost savings in fewer crew changes because of reduced radiation dose.

Dose Reduction During Reactor Operation

A $5 \%$ reduction of the annual operation and maintenance dose of 416 man-rem (this excludes refueling; see Table 2.3-1) results in an annual radiation dose reduction of 21 man-rem, or 840 man-rem over the 40-year life-time of the plant. Dose Reduction During Decommissioning

A $5 \%$ reduction of the 437 man-rem (see Table 2.1-1) acquired in decontaminating and dismantling equipment in the reactor building (210 man-rem) other than the pressure vessel, the pressure vessel internals, and the steam generators; and equipment in the auxiliary building (227 man-rem), would result in a dose reduction of 22 man-rem from the installation of pipe shielding.

\subsection{COST AND OOSE ESTIMATES FOR CASE II: SHIELDED VEHICLE}

Estimates of the costs and radiation dose reductions resulting from the use of a shielded vehicle are presented below.

\section{Capital Costs}

Capital costs include the costs of increased size of buildings to accommodate the vehicles and the costs of the vehicies themselves. Adding $20,000 \mathrm{ft}^{2}$ at $\$ 200 / \mathrm{ft}^{2}$ would cost $\$ 4,000,000$. Additional ramps, widened doors, and handling facilities for the vehicles would add $\$ 500,000$. At $\$ 100,000$ each, three vehicles (one for each building, plus a spare) would cost $\$ 300,000$. The total capital cost would be approximately $\$ 4,800,000$.

\section{Costs During Reactor Operation}

Maintenance would require the attention of one mechanic half-time for 40 years at $\$ 25,000 /$ year, or $\$ 500,000$. An increased operation and maintenance efficiency of $5 \%$ for four men (two in each vehicle) each year would result in a cost saving of $\$ 200,000$ over 40 years. 
Costs During Decommissioning

Maintenance would require the attention of one mechanic half-time for 3 years at $\$ 25,000 /$ year, or $\$ 37,500$. An increased decommissioning efficiericy of $5 \%$ for four men over three years would result in a cost saving of $\$ 15,000$. Dose Reduction During Reactor Operation

A shielded vehicle could be useful to some extent in all maintenance work. A radiation dose reduction of $5 \%$ of 450 man-rem per year would amount to 900 man-rem over 40 years.

Dose Reduction During Decommissioning

A shielded vehicle could be useful in almost all decommissioning activities. A $5 \%$ deconmissioning dose reduction is 54 man-rem. 


\subsection{REDUCTION OF RADWASTE VOLUME BY INCINERATION}

Incineration of combustible contaminated wastes could reduce the volume of material that must be handled, packaged, shipped, and disposed of by burial during both maintenance and decomissioning. Present practice reduces the volume of these wastes by a factor of 5 to 1 (Reference $3, p$. G-33); incineration could reduce the volume by an additional factor of 5 to 1 .

This alternative could be implemented either just before decommissioning, or at the time of reactor design to take advantage of incineration during reactor operation and maintenance. The principal advantage of this alternative is the reduction in volume of radioactive wastes that must be buried. Some reduction of radiation dose would occur through efficiencies in waste handling and shielding.

Dose reduction is estimated to be 50 man-rem during operation and maintenance and 2 man-rem during decommissioning, at a capital cost of $\$ 2,000,000$, with cost savings of $\$ 2,764,000$ and $\$ 125,000$ during maintenance and decommissioning, respectively. Some structural redesign might be necessary to house the incinerator.

\subsection{DISCUSSION}

At least two types of incineration processes are possible: 1) a solid material burning unit, and 2) a more versatile solid/liquid handling unit. The solid handling unit has an established technological history and is in wide use, while the solid/liquid unit is a more recent development. For this reason the solid unit will be discussed here, except for the following paragraph.

A solid/liquid process has been developed, under the title "PWR-1," by Newport News Industrial Corporation, ${ }^{(14)}$ and is planned for installation at Nine Mile Point Nuclear Station. It combines evaporation and combustion in a fluidized bed system, treating liquid and solid wastes in separate cycles at different temperatures, and collecting the solid combustion products in cyclone separators. It provides greater versatility than the solid unit, since it processes wet, as well as dry, materials and can supplant the radwaste concentration system. The capital cost, including ash solidification capability 
and liquid concentration, is $\$ 2,500,000$ to $\$ 3,500,000$. It requires 1 ess than a full-time operator's time. The liquid concentration portion of the solid/ 1 iquid process would cost slightly less than $\$ 1,000,000$, indicating that the capital cost of the solids reduction portion of this process alone might be in the same general range as the solid burner unit. Further development may well make this system very attractive, since volume reductions appear to be much greater than for solid incineration alone. This would, in turn, result in Tess waste to be handled and less cost.

The solid material burning facility includes an incinerator fired by available fuel (i.e., oil, gas), an afterburner, a heat exchanger/economizer, a filter chain (i.e., bag and HEPA), a stack equipped with off-gas monitoring capability, and ash collection and packaging facilities. Extensive off-gas treatment is not considered necessary because of the low specific activity of the contaminated waste and the absence of highly toxic constituents in the waste. The unit would be sized to accommodate at least two reactors with a capacity in the range of 2,000 Tb per daily cycle (uncompacted combustible waste would weigh approximately $\left.81 \mathrm{~b} / \mathrm{ft}^{3}\right) .{ }^{(15)}$ The installation of this unit would require approximately $26,000 \mathrm{ft}^{3}$ of building space.

It is assumed that radiation concentration by incineration will not be so excessive as to require special handling and that operation of the incinerator ${ }^{(16)}$ will involve negligible dose.

Combustible waste is reduced in volume by a factor of approximately 5 to 1 , if compaction is used. With incineration, an additional reduction by a factor of approximately 5 would be achieved. A large LWR averages $45,000 \mathrm{ft}^{3}$ of waste annually. (17) of this, $5,000 \mathrm{ft}^{3}$ is compacted trash, with an 85 to $100 \%$ combustible content. Since this is generally of a low specific activity (about $\left.1 \mathrm{Ci} / 1,000 \mathrm{ft}^{3}\right),{ }^{(15)}$ disposal without volume reduction would constitute inefficient burial site usage.

The decomissioning operation is expected to generate approximately $16,700 \mathrm{~m}^{3}\left(600,000 \mathrm{ft}^{3}\right)$ of contaminated material (Reference 3 , Tables $6.4-2$ and 6.4-6), of which compacted combustible waste amounts to about $290 \mathrm{~m}^{3}$ $\left(10,000 \mathrm{ft}^{3}\right)$. 
The incinerator could thus be utilized on approximately $5,000 \mathrm{ft}^{3}$ of compacted combustible waste annually, and $10,000 \mathrm{ft}^{3}$ of compacted combustible waste during decomnissioning. Reducing these volumes further by a factor of five by incineration would lead to substantial transportation and burial cost savings, as well as to substantial savings in land area required to be committed to the burial of low-level waste.

\subsection{COST AND DOSE ESTIMATES}

Estimates of the cost and radiation dose reductions resulting from the installation and operation of an incinerator are presented below.

\section{Capital Costs}

An incinerator servicing a twin reactor site would involve a capital expenditure of approximately $\$ 2,000,000$.

\section{Costs During Reactor 0peration}

From Table 6.4-6 in Reference 3 , the cost to dispose of a 208- $\ell$ drum containing compacted low-level waste is approximately $\$ 150$. This includes the cost to rent and transport casks, which might be required to shieid approximately one-third of the drums. Each drum will contain $7.35 \mathrm{ft}^{3}$ of waste, so a total of 680 drums will be required to dispose of the $5,000 \mathrm{ft}^{3}$ of waste. A 5 to 1 reduction in the amount of waste buried is a reduction from 680 drums to 146 drums/year, or a saving of 544 drums/year. Over 40 years, a saving of 544 drums/year results in a total disposal cost saving of $\$ 3,264,000$. Maintenance of this incinerator would require the services of one mechanic half-time at a full-time cost of $\$ 25,000 /$ year, or $\$ 500,000$ over 40 years. The net operating saving would be $\$ 2,764,000$.

\section{Costs During Decommissioning}

From Table 6.4-6 in Reference 3, the cost to dispose of 1,350 drums of compacted low-level waste is $\$ 207,431$, or approximately $\$ 150 /$ drum. Again, this cost includes cask rental and transport costs for those drums requiring shielding. A reduction in volume of 5 to 1 by incineration will result in a reduction of 1,080 drums to be shipped, at a cost saving of $\$ 162,000$. Three-year maintenance costs would be $\$ 37,500$, for a net decomissioning cost saving of $\$ 125,000$. 
Dose Reduction During Reactor Operation

Some radiation dose reduction would be expected in plant operation and decommissioning from incineration because of the reduced volume of low-level radioactive material that must be handled and shipped. Even though no radioactivity disappears, and all of it is concentrated into a smaller volume, the smaller volume would lend itself to efficiencies in handling and radiation protection. A 5\% reduction in the 22 man-rem associated with waste processing (Table 2.3-1) would result in an occupational radiation dose reduction of 44 man-rem over 40 years.

If decommissioning waste handling dose data from Reference 3 are applicable to waste handling during reactor operation, then Table 11.4-2 from Reference 3 may be interpreted to show a dose to transportation workers of $72.6 \times 10^{-3}$ man-rem per shipment and a dose to the public of $15.4 \times 10^{-3}$ manrem per shipment. The annual waste production of 680 drums (without incineration) will require 31 shipments. A $5 \%$ dose reduction will resuit in a dose reduction of 5 man-rem to transportation workers over 40 years and a dose reduction of 1 man-rem to the public, or a total radiation dose reduction of 50 man-rem during reactor operation.

Dose Reduction During Decommissioning

The radiation dose to workers and to the public from handling contaminated, combustible wastes is 30 man-rem: 24.8 man-rem from packaging (Table 2.1-1), 4 man-rem to transportation workers from handling 60 shipments, and 1 man-rem to the pubtic from the same 60 shipments. A $5 \%$ reduction of the 30 man-rem is a decomissioning reduction of 2 man-rem. 


\subsection{ELECTROPOLISHING}

Electropolishing of metal pipes and equipment prior to installation has been demonstrated as a satisfactory way of poijshing internal surfaces to minimize later build-up of surface radioactivity. (18) It has also been demonstrated as a satisfactory technique for decontaminating piping, radwaste equipment, and smal1 metal objects, both routinely during maintenance outages and during decommissioning. This is particularly true when vibratory finishing can be used as a preparatory treatment. Opportunities for use of electropolishing are substantially greater during reactor construction and decommissioning than they are during routine maintenance. This results in the availability of two options for the installation of electropolishing equipment. One option is to install a unit during construction that is large enough to handle construction and decommissioning, which then becomes more than adequate to handle electropoishing during routine maintenance. The other option is to install electropolishing equipment only large enough to handle routine maintenance, and to supplement the permanent equipment with mobile equipment during construction and decommissioning. The first alternative is discussed here.

Implementation of electropolishing would begin at the design stage and continue through construction, operation, and decommissioning. The principai advantages of electropolisshing are reduced radiation doses from maintaining and decommissioning various components of the primary cooling loop, and the possibility of reclaiming some equipment and materials.

It is estimated that the occupational radiation dose during operation and maintenance could be reduced by 640 man-rem over the 40-year lifetime of the plant, that the occupational radiation dose during deconmissioning could be reduced by 22 man-rem, that the capital costs of implementing this al ternative would be $\$ 840,000$, that operational costs would be increased by $\$ 500,000$, and that decommisisoning costs would be reduced by $\$ 598,000$. There would be an impact on the structure of the facility to provide space for the electropolishing apparatus. 


\subsection{DISCUSSION}

The buildup of radioactive contaminants on internal and external surfaces during reactor operation contributes radiation dose to the operators during maintenance and to the decommissioning crew at the end of plant life. Decontamination by flushing the systems with chemical solutions has been used to achieve some reduction of dose. Another decontamination technique is electropolishing. This technique uses electroplating techniques in reverse to remove minute depths of metal surfaces. Surface contamination in nuclear plants consists of deposition and plating of radioactive corrosion products on the internals of the recirculating and radwaste systems. Electropolishing removes the underlying metal, and with it the contamination; and thereby provides a method for concentrating contaminants for removal. The process also removes surface imperfections, thereby forming a smoother surface, which inhibits the adherence of contaminants.

Vibratory finishing can be used to prepare metal surfaces for electropolishing. This technique utilizes small abrasive particles that are vibrated at high frequency in a cleaning-solution medium to remove paint, tape, grease, rust, and other surface coatings from the metal to be electropolished. This technique has also been shown to be effective in removing contamination from non-metallic objects, such as glove box materials, to the extent of converting transuranic waste to non-transuranic waste. (18)

The facility would be used during construction to prepolish new metallic components and during plant operation (approximately 40 years) to decontaminate tools and reusable components. During decommissioning, it would be used for decontamination of portable equipment, as well as for in-situ decontamination of fixed components, to provide a reduction in dose and in volume of burial wastes, and to provide an increase of reclaimable material.

The advantages of electropolishing in an operating plant are three-fold: 1) prepolishing in a new plant could inhibit the adherence of contaminants to metals and thereby reduce cleanup dose during maintenance, 2) in-situ electropolishing could reduce maintenance dose, and 3) batch electropolishing could decontaminate reusable metal components and maintenance tools to background levels. In-situ decontamination would require portable equipment from the 
electropolishing facility in order to reduce dose prior to maintenance efforts on in-place equipment. New replacement components could be electropolished at the plant site prior to installation.

In decommissioning, cleanup of contaminated but non-activated components will reduce the volume of material requiring packaging, transportation, and burial. Electropolishing will not, of course, reduce the total amount of radioactivity; it will, however, remove radioactivity from some components that cannot be serviced or decommissioned without incurring substantial radiation dose, and will concentrate the radioactivity into more convenient forms for handling and disposal.

\subsection{COST AND DOSE ESTIMATES}

Estimates of the costs and radiation dose reductions resulting from electropolishing are presented below.

\section{Capital Costs}

An electropolishing facility would require a compartmented area measuring about $90 \mathrm{ft}$ by $60 \mathrm{ft}$, or $5,400 \mathrm{ft}^{2}$. The equipment polishing and rinsing tank for processing components up to $20 \mathrm{ft}$ long and $3 \mathrm{ft}$ in diameter would cost an estimated $\$ 300,000$. Building costs at $\$ 100 / \mathrm{ft}^{2}$ would add an additional $\$ 540,000$, for a total of $\$ 840,000$. The facility would be used initially for new piping, throughout the 1 ife of the plant to provide decontamination, and, at the end of the plant's useful life, to facilitate decomissioning.

Construction of a commercial electropolishing facility prior to decommissioning at a plant not presently equipped with one would have no economic advantage, because mobile electropolishing facilities are available for lease from several firms. The schedule and sequence of events (Reference 3 , Table 9.1-2) indicate that the electropolishing period would span a total of 9 months of continuous duty. Although the individual spans are not concurrent, it may be possible to store early dismantled equipment to permit the electropolishing process to be continuous. 
Costs During Decommissioning

Approximately 2,000,000 ib of contaminated stainless steel from areas outside of the PWR containment building must be removed, packaged, and buried. All of this stainless steel is potentially salvageable by electropolishing techniques. If half of this material could be reclaimed for reuse, approximately $\$ 610,000$ could be saved, assuming a $\$ 0.34 / 1 \mathrm{~b}$ disposal cost and a $\$ 0.27 / 1$ b salvage value (see Reference $3, p .10-3$ ). Reclamation of stainless steel from the containment buiding and carbon steel from outside the containment building would increase the saving.

Maintenance of the electropolishing facility for 1 year during deconmissioning would cost $\$ 12,500$.

Oose Reduction During Reactor Operation

Routine and special maintenance radiation doses total 321 man-rem per year (Table 2.3-1). A 5\% dose reduction is 16 man-rem, or 640 man-rem over 40 years. Dose Reduction During Decommissioning

The radiation dose from components amenable to electropolishing in the reactor and auxiliary buildings totals 434 man-rem (Table 2.1-1). A radiation dose reduction of $5 \%$ is 22 man-rem. 


\subsection{REMOTE MAINTENANCE AND DECOMMISSIONING EQUIPMENT}

Remote-controlled equipment offers the possibility of carrying out maintenance, monitoring, and decommissioning activities in high-radiation fields where contact maintenance results in excessive occupational radiation doses. A state-of-the-art robot could perform basic maintenance and decommissioning functions at a substantial saving in radiation dose.

For a small robot (i.e., a robot that could maneuver in the space available), implementation of this alternative could begin at the time of decommissioning of an existing reactor. A larger robot would require implementation at the design stage of the structure in order to ensure sufficient operating room for the robot.

It is estimated that the occupational radiation dose during operation and maintenance could be reduced by 800 man-rem over the 40 -year 1 ifetime of the plant, that the occupational radiation dose during decomissioning could be reduced by 54 man-rem, that the capital costs of implementing this alternative would be $\$ 100,000$, that operational costs would be increased by $\$ 500,000$, and that decommissioning costs would be increased by $\$ 38,000$.

\subsection{DISCUSSION}

Remote operation to replace human functions had its beginning during this century, principally since the early 1950s. In this period the computer came into use to provide, in addition to computation capability, information storage and operation control. There are now remote units, sometimes given the generic title of "robot," that are programmed to deliver office mail (fabrication cost: $\$ 12,000$ ) and to simulate the human functions of walking, talking, and writing, while being directed from a control unit 2 miles distant (fabrication cost: $\$ 1,000,000)$. The National Science Foundation is developing a mobile unit at a cost of $\$ 400,000$ to perform work in hazardous or fragile environments. The Federal Republic of Germany has developed a very sophisticated unit weighing almost 4 tons that can perform a vast number of complex functions for its nuclear emergency brigade. The current state-of-the-art is such that all of the key human control activities can be simulated at a price generally ranging up to $\$ 1,000,000$. 
The performance of radiation surveillance, simple routine maintenance, and visual examination in medium- to high-radiation fields causes inefficient use of personnel because of limited residence time in these areas. Remote, normanned equipment that can perform these functions would reduce personnel dose and provide more efficient utilization of these personnel.

A reliable remote unit capable of carrying out these tasks should require little maintenance, be reasonably compact, be reasonably inexpensive, be readily decontaminable, be mobile (both unit and console), and be remotely controlled. Ordinary industry requirements include limited space capability, operation in a range of temperatures and hazardous rocations (i.e., little or no air, underwater), and ability to perform boring jobs without fatiguing. Nuclear requirements differ from these only in that they require operation in radiation fields. Reliability cannot be over emphasized, since a breakdowr. in service would not only delay a key operation, but could also compound the situation by adding robot removal and repair to the problem at hand.

\subsection{COST AND DOSE ESTIMATES}

Estimates of the costs and radiation dose reductions resulting from installation and operation of a robot are given below.

Capital Costs

Table 12.2-1 characterizes the potential unit in terms of step-wise physical additions and incremental functions gained with each addition, along with estimated costs based on a custom-designed and -constructed unit. This table shows that the need for a PWR general service remote unit would be best satisfied with a unit containing components through Item $V$, a simple manipulator plus TV, hoist, and extendable mast. The cost of this unit (with a contingency allowance) would be approximately $\$ 100,000$. It would have the following maintenance capabilities: simple radiation survey, placing shieiding blankets, moving or lifting small objects (i.e., drums, liquid filters), operating valves, making connections, and tightening nuts. 


\section{TABLE 12.2-1. Remote Maintenance Unit Functions and Costs}

\begin{tabular}{|c|c|c|c|c|}
\hline \multicolumn{2}{|c|}{ Component } & Features & $\begin{array}{l}\text { Incremental cost } \\
(\$ \text { thousands }) \\
\end{array}$ & Functions \\
\hline \multirow[t]{4}{*}{ I. } & Basic Unit & & 50 & $\begin{array}{l}\text { Hobility under remote } \\
\text { control }\end{array}$ \\
\hline & Structure & $\begin{array}{l}\text { Metal, compact, enclosed, } \\
\text { easily decontaminable }\end{array}$ & & \\
\hline & Power & Battery; $A C$ as alternate & & \\
\hline & Control & Radio (remote control) & & \\
\hline II. & TV Capability & $\begin{array}{l}\text { Multiple heads; } 360^{\circ} \\
\text { turn, tilting; receiver } \\
\text { at console }\end{array}$ & 15 & Visibility \\
\hline III. & Extendable Mast & Retractable & 2 & Radiation monitoring \\
\hline IV. & Fork Lift Hoist & 1-ton capacity & 5 & Moving small objects \\
\hline V. & Simple Manipulator & $\begin{array}{l}\text { Minimum capabilities; } \\
\text { nondirectional; } \\
\text { grip/release; retractable }\end{array}$ & 18 & $\begin{array}{l}\text { Valving, placing } \\
\text { temporary shielding; } \\
\text { simple connect/disconnect }\end{array}$ \\
\hline VI. & Water/Air Supply & $\begin{array}{l}\text { Self-reeling hoses; hose } \\
\text { channels; directional } \\
\text { nozzle }\end{array}$ & 15 & Wash-down decontamination \\
\hline \multirow[t]{2}{*}{ VII. } & $\begin{array}{l}\text { Median Capability } \\
\text { Manipulator }\end{array}$ & $\begin{array}{l}\text { Multi-directional; } \\
\text { elbowed; retractable }\end{array}$ & $\begin{array}{r}50 \\
-\end{array}$ & $\begin{array}{l}\text { Sampling, insulation } \\
\text { remova] }\end{array}$ \\
\hline & Total & & 155 & \\
\hline
\end{tabular}

\section{Costs During Reactor Operation}

Operation and maintenance costs would be about $\$ 12,500 /$ year, or $\$ 500,000$ over 40 years. This corresponds to one man half-time to operate and maintain the robot.

Costs During Decommissioning

Decommissioning costs would include the cost to operate and maintain the robot for 3 years. For one person half-time, at a full-time cost of $\$ 25,000$ per year, this totals $\$ 37,500$. 
Dose Reduction During Reactor Operation

A $5 \%$ dose reduction resulting from the use of a robot in reactor operations and surveillance, routine maintenance, in-service inspection, and specia] maintenance (394 man-rem total from Table 2.3-1) is 20 man-rem/year, or 800 man-rem over 40 years.

Dose Reduction During Decommissioning

A robot would probably be useful to some extent in almost all aspects of decommissioning. A $5 \%$ reduction of the total decommissioning radiation dose of 1,083 man-rem (Table 2.1-1) is 54 man-rem. 


\subsection{PRIMARY COOLANT SYSTEM OECONTAMINATION}

The substantial contributions to radiation dose from the primary loop, both in maintenance and in decommissioning, suggest that a further discussion of decomnissioning the primary loop is warranted. Chemical decontamination and electropolishing, two possible choices for facilitating decontamination of the primary loop, are discussed here. No cost or dose reduction calculations are presented.

\subsection{DISCUSSION}

The primary coolant system of a power reactor acquires surface contamination from activated impurities and corrosion products that are carried through the core during reactor operation. Essentially all contamination is either trapped in crevices or is smeared (plated) on the inside surfaces of pipes, valves, and rotating equipment. The known methods of decontamination are chemical decontamination and electropolishing. Both methods remove surface layers: chemical decontamination usually removes just the corrosion products, while electropolishing removes some of the underlying metal as well. Because the primary loop entails such a large surface area and because it is the primary source for liquid contamination of the entire plant, it has a major potential for dose reduction.

The magnitude of the radiation dose problem can be seen by noting the massive internal surface areas that are involved. A total piping surface of $39,000 \mathrm{ft}^{2}$ can be calculated from Table A.3-5 in Reference 3. Steam generators each have an additional $51,500 \mathrm{ft}^{2}$ of surface, for a total of $206,000 \mathrm{ft}^{2}$, if four are present. The pressurizer adds $1,000 \mathrm{ft}^{2}$, and miscellaneous tanks and heat exchangers, another $8,200 \mathrm{ft}^{2}$, for an overall total of about $250,000 \mathrm{ft}^{2}$ of internal surface area. Since the piping and steam generators comprise a 1 but about $10,000 \mathrm{ft}^{2}$ of the surface area, a major opportunity for dose savings would be in these two components. 
Design criteria to facilitate primary loop decontamination include l) changes that would minimize crud (corrosion product) traps, and 2) changes that would either improve decontamination efficiency or make the decontamination process simpler to operate.

Operating experience indicates the need to minimize crud traps in the primary loop, although there are no quantitative requirements because it is impractical to establish uniform internal smoothness throughout the system. Weld joints, valve seats, and rotating equipment are examples of areas where smoothness tolerances would be impractical to meet. Nevertheless, the smoother the surface of a liquid system, the less conducive it will be to crud trapping and plating of corrosion products.

The design of chemical decontamination systems to be an integral part of the nuclear plant has been done only in isolated instances in the past; the Hanford $\mathrm{N}$ reactor has one such system. Isolating capabilities are essentially nonexistent in the present generation of commercial nuclear plants. Some utility customers are requesting connective stub-outs to be included in the primary loop to facilitate any decontamination of the system that might be required; however, any isolation required would have to be installed during the decontamination process and removed prior to startup.

Decontamination experiments ${ }^{(18)}$ presently under way utilizing electropolishing techniques show considerable potential in reducing the contamination level of wastes to a level that will permit reclamation. Some experimentation has also taken place utilizing in-situ methods to electropoish reactor components at Hanford $\mathrm{N}$ reactor. This type of decontamination technique has been proven in principle; however, each application requires the setting up and subsequent disassembly of specialized equipment. The process requires isolation of the component, installation of a cathode, introduction and draining of an electrolyte, and the application of DC power.

Cathodes installed in lengths of the larger-bore primary loop piping would permit electropolishing to be used for periodic decontamination. However, installed cathodes in the primary coolant system would be difficult to maintain leak-free during operation, since electrically insulated seals for 
operation at high pressures and temperatures are difficult to make and maintain. It would be better to provide for convenient installation of temporary cathodes when the system is to be decontaminated. Power connections to the cathode would be necessary at intervals that would vary in length, depending on the diameter of the pipe. The length of pipe interval and number of times the power supply would have to be moved would be controlled by the power requirements of the process. Presently, power supplies of 5,400 amperes DC are routinely used in electropolishing facilities. Average current densities of 150 amperes $/ \mathrm{ft}^{2}$ have been used to remove 0.3 to $2.0 \mathrm{mils}$ of surface material. This would limit the electropolishing area for each increment to $36 \mathrm{ft}^{2}$. Cathode length increments and, consequently, connection terminals would range from about $4.5 \mathrm{ft}$ in length for $30-\mathrm{in}$.-diameter pipe to $17 \mathrm{ft}$ for 8 -in. pipe, and $22 \mathrm{ft}$ for $6-i n$. pipe. Installation of a movable cathode that travels slowly down the pipe is also a possibility. 



\subsection{SPECIAL DECOMMISSIONING TOOLS AND TECHNIQUES}

Unique problems caused by the presence of radiation fields call for the development of special decommissioning tools and techniques that speed cutting, drilling, and separation of radioactive components or that permit deconmissioning workers to carry out their activities in lower radiation fields. Such tools and techniques that also reduce radiation dose to maintenance workers are especially desirable. Possible options include plasma arc torch improvement, arc saw improvement, thermic lancing and/or oxyacetylene cutting improvement, explosive cutting, a mobile, shielded crane-mounted enclosure, and internal heating of the biological shield.

Development of special tools and techniques could begin at any time up to the actual start of decomissioning, and could continue into the decommissioning process.

No estimates of dose or cost savings are given here because each tool or technique would call for a separate evaluation, and the result for each tool or technique would probably show only a modest dose reduction because of limited applicability. The total contribution to decommissioning and maintenance dose reduction of several special tools and techniques could, however, be substantial, as could be the total development costs. There would be little impact on the structure from the development of special tools and techniques.

\subsection{DISCUSSION}

Inspection of Table 2.1-1 shows that some two-thirds of the radiation dose associated with dismantling a PWR is associated with removing components of the primary cooling loop. Improved decontamination methods (discussed in Section 13.0), improved cutting tools, and improved handling methods could substantially reduce the radiation dose associated with removing components of the primary loop. Specific tools or techniques include the plasma arc torch, the arc saw, explosive cutting, and a crane-mounted, shielded work station.

The plasma arc torch (see Reference 3, Section F) is a metal-cutting device operated either in air or under water in which a high-temperature, 
high-velocity, small-diameter gaseous arc is struck between an electrode in the torch and the metal piece to be cut. The combined heat and force of the arc stream melt the metal and produce a high-quality, saw-like cut. The required improvements include the development of improved manipulation techniques and the development of torches that would cut thicker pieces of steel. The plasma arc torch used to dismantle the Elk River reactor was able to cut 1.5-in.-thick stainiess steel under water and 3.5-in.-thick carbon steel in air. For larger reactors, torches will be needed that would cut 2-3/4-in.thick stainless steel under water and 9-in.-thick carbon steel in air (see Reference 19, p. 2-21).

A prototype arc saw has been developed (see Reference 3, Section F) with a 36-in.-diameter saw blade capable of being operated either in air or under water. Scaling up the saw blade to a diameter of $10 \mathrm{ft}$ appears to be feasible, which would allow cutting large-diameter pipes, heat exchangers, and tanks.

Explosive cutting appears particularly well-adapted for removing pipes up to $1.5 \mathrm{in}$. thick or for cutting small pieces of difficult geometry. Its particular advantages include unattended operation and ability to operate in areas inaccessible to other cutting techniques. Design work is needed to solve the problems of water pluming in underwater cuts, of insuring good expiosive-to-surface contact, and of placenent on difficult-to-reach surfaces.

A shielded, crane-mounted enclosure would permit direct observation and control of decommissioning operations being handled by the crane. It would also protect personnel conducting operations in the spent fuel storage pool or pressure vessel from intense radiation fields. 


\section{APPENDIX A}

Note 1. From Reference 3, Table A.3-6, Figures G.2-3 and G.2-4, fuel and auxiliary building equipment and piping weighing about $775,000 \mathrm{lb}$ is dismantled at a labor cost of $\$ 520,000$, or about $\$ 0.65 / \mathrm{lb}$. Periodic changeout of pieces for maintenance or replacement is estimated to cost about the same. However, only portions of the equipment will require maintenance or replacement over the lifetime of the reactor, so the rate of $\$ 0.65 / 1 \mathrm{~b}$ is arbitrarily applied to one-half the weight of the equipment. The pressurizer weighs 195,000 1b (Table G.4-4).

From page G-45 of Reference 3 , the cost of concrete removal is $\$ 60 / y d^{3}$. 
Note 2 .

TABLE A-1. Data on Burial of Activated Materials from the Containment Building (from Reference 3, Table G.4-3)

\begin{tabular}{|c|c|c|c|c|c|c|}
\hline Component & $\begin{array}{c}\text { Weight } \\
\text { (ib) }\end{array}$ & $\begin{array}{c}\text { Estimated } \\
\text { Radioactivity } \\
\text { (Ci) }\end{array}$ & $\mathrm{Ci} / \mathrm{lb}$ & $\begin{array}{c}\begin{array}{c}\text { Number } \\
\text { of Waste } \\
\text { Containers }\end{array} \\
\end{array}$ & $\begin{array}{c}\text { Total } \\
\text { Burial Cost }\end{array}$ & $\begin{array}{r}\text { Disposal } \\
\text { Cost } / 7 \mathrm{~b} \\
\end{array}$ \\
\hline Pressure Vessel & 875,500 & 19,200 & 0.02 & 78 & $\$ 1,022,000$ & $\$ 1.17$ \\
\hline \multicolumn{7}{|l|}{ Reactor } \\
\hline Internals & 421,100 & $4,821,500$ & 11.5 & 88 & $\$ 1,471,000$ & $\$ 3.49$ \\
\hline Core Shroud $(a)$ & 27,100 & $3,431,000$ & 127 & 4 & $\$ 246,000^{(b)}$ & $\$ 9.108$ \\
\hline Bio Shield & $21,950,000$ & $<2,000$ & -- & 195 & $\$ 235,000$ & $\$ 0.12$ \\
\hline $\begin{array}{l}\text { Reactor Cavity } \\
\text { Liner }\end{array}$ & 232,000 & $\leq 10$ & --- & 4 & $\$ \quad 4,800$ & $\$ \ldots$ \\
\hline Total & $3,729,000$ & $<4,843,000$ & 1.5 & 365 & $\$ 2,733,000^{(c)}$ & $\$ 0.33$ \\
\hline
\end{tabular}

(a) The core shroud figures are included in the figures for reactor internals, and are therefore already included in the totals.

(b) Includes $\$ 192,165$ in curie surcharge.

(c) Includes $\$ 296,000$ in curie surcharge.

From Section G.4.2.2 of Reference 3, the radioactivity in contaminated material shipped to burial is $1000 \mathrm{Ci}$. 
Note 3 . The capital cost of internal concrete structures is estimated at $\$ 8,452,585$ for $10,000 \mathrm{yd}^{3}$ of concrete (Reference 10 , Section 3 , volume 1 , account number 212.1413 ). This is an average of $\$ 845 / \mathrm{yd}^{3}$, installed. Forming of the additional holes for later insertion of explosives is estimated at an additional $5 \%$ of the capital costs. The biological shield contains $960 \mathrm{yd}^{3}$ of concrete (Reference 3, Table A.2-1), which would cost $\$ 811,000$ in place. An increase of $5 \%$ would result in a $\$ 41,000$ cost increase.

The concrete bioshield averages about $4.5 \mathrm{ft}$ thick. For blasting, three rings of holes are needed, for a total of about 550 holes. The drilling of these holes is estimated to require 264 man-days. At $\$ 100 /$ man-day this would be a $\$ 26,400$ labor cost under decommissioning radiation conditions. One-third of this cost would still be needed for uncapping the preformed holes and removing sand by remote-controlled pneumatic suction hoses and nozzles. Two-thirds would be saved, or $\$ 17,600$.

In the case of a modular design, the structural steel frame with steel plate liner on both sides is estimated to require 544 tons at $\$ 1010 /$ ton, or $\$ 550,000$. The precast panels will consist of 16 layers, each 4.5 in. thick. The average surface area of each layer for a 100-ft-high shield would be $10,630 \mathrm{ft}^{2}$ (Reference 3, Figures A.2-2 and C.1-1). The cost of these panels is estimated at $\$ 11.50 / \mathrm{ft}^{2}$, for a total of $\$ 1,956,000$. This, plus $\$ 550,000$ for the steel frame, would total $\$ 2,506,000$. The difference between the cost of the modular design $(\$ 2,506,000)$ and the cost of the concrete design $(\$ 811,000)$ is $\$ 1,695,000$. 
Note 4. It is assumed that the contaminated concrete that must be removed and buried results from contamination to a depth of 6 in. in unlined areas and to a depth of approximately $4 \mathrm{in}$. in submerged pools that are lined with stainless steel liners. The area of lined submerged pools and containment building areas subject to periodic submersion is calculated as follows: Lined areas (Reference 10, Items 212.14136 and 217.129) amount to a total of $26,000 \mathrm{ft}^{2}$, with an average cost of installed liner of $\$ 89 / \mathrm{ft}^{2}$. The principal contributors (Reference 3, Tables G.4-4 and G.4-5) of contaminated concrete are:

\begin{tabular}{|c|c|c|}
\hline Containment Building & $\begin{array}{l}\text { Ib of } \\
\text { Steel }\end{array}$ & $\begin{array}{c}\text { 1b of Contaminated } \\
\text { Concrete }\end{array}$ \\
\hline Refueling Cavity Liner & 38,000 & 608,000 \\
\hline Pressurizer Enclosure & 0 & 540,000 \\
\hline Steam Generator Enclosure & 0 & $1,060,000$ \\
\hline $\begin{array}{l}\text { Base Slab Liner and } \\
\text { Concrete }\end{array}$ & $\underline{120,000}$ & $\frac{1,150,000}{3,350,000}$ \\
\hline
\end{tabular}

Other Buildings

\begin{tabular}{lcr} 
Fuel Storage Pool (304 SS) & 75,000 & 720,000 \\
Other Contaminated Concrete & $\cdots$ & $\underline{25,654,000}$ \\
Total Contaminated Concrete & & $\underline{26,374,000}$ \\
\hline & & $29,732,000$
\end{tabular}

Unlined areas from "other buildings" contribute a total of 25,654,000 ib of contaminated concrete. It is these areas that are considered here. Assuming an average 6-in. depth of contamination, the area from which this concrete originated must have been:

$$
\frac{25,654,000 \mathrm{lb}}{144 \mathrm{lb} / \mathrm{ft}^{3}} \times \frac{12 \mathrm{in} . / \mathrm{ft}}{6 \mathrm{in.}}=356,300 \mathrm{ft}^{2}
$$

This is the area that must be protected from contamination outside of the containment building to reduce the volume of contaminated concrete requiring disposal. 
The carbon steel liners in the containment building are estimated to cost $\$ 10,527,706$ (Reference 10, Item 212.146). Material costs are $\$ 6,381,706$. However, the category includes stiffeners and penetrations for a building that has an excess number of penetrations. This category cannot be used to estimate the costs of simple liner plate in typical building walls. Materials costs from Reference 10, Items 212.14136 and 217.139 , indicate the cost of stainless steel liner plate at $\$ 35 / \mathrm{ft}^{2}$. Installed unit costs for these submerged areas average $\$ 89 / \mathrm{ft}^{2}$. A conservative estimate for lower-cost carbon steel plate and a less-exacting installation would be two-thirds of the stainless steel installed cost, or $\$ 59 / \mathrm{ft}^{2}$.

Actual on-the-job experience ${ }^{(20)}$ indicates an average of $53 \mathrm{sec} / \mathrm{ft}^{2}$ to drill and spall to a depth of 2 in. Disposal of the 25,654,000 lb of concrete resulting from spalling $356,300 \mathrm{ft}^{2}$ to a depth of 6 in. would cost $\$ 3,078,000$. Four in. requires $106 \mathrm{sec} / \mathrm{ft}^{2}$ of labor and $6 \mathrm{in}$. requires $159 \mathrm{sec} / \mathrm{ft}^{2}$. Special work clothing and masks permit $6 \mathrm{hr}$ of useful work out of an 8-hr work day.

$$
\begin{aligned}
& \frac{356,300 \mathrm{ft}^{2}(6 \mathrm{in} \text {. deep })}{6 \mathrm{hr} / \mathrm{man}-\mathrm{day} \times 60 \mathrm{~min} / \mathrm{hr} \times 60 \mathrm{sec} / \mathrm{min}} \times 159 \mathrm{sec} / \mathrm{ft}^{2} \times \$ 100 / \text { man-day }= \\
& 2,623 \mathrm{man} \text {-days } \times \$ 100 / \text { man-day }=\$ 262,300 \text { work el iminated for concrete } \\
& \text { spal1ing }
\end{aligned}
$$

From Table G.4-5 of Reference 3, the cost of disposal of contaminated concrete is $\$ 0.12 / 1 b$. 
Note 5. The existence of a special shielded maintenance shop is estimated to improve both maintenance and decommissioning by $5 \%$. A labor cost of $\$ 0.67 / 1 \mathrm{~b}$ to decommission equipment in the fuel and auxiliary buildings is calculated as follows:

$$
\frac{\$ 210,170^{(a)}+\$ 309,702^{(b)}}{775,0001 b^{(c)}}=\$ 0.67
$$

A $5 \%$ cost saving is a saving of $\$ 0.03 / 1 \mathrm{~b}$.

The weight of equipment in the containment building that could be decommissioned in a special shielded maintenance shop is $5,460,000$ lb.

\begin{tabular}{|c|c|c|c|}
\hline Steam Generators & 4 & (a) $700,0001 \mathrm{lb}=$ & $2,800,0001 \mathrm{t}$ \\
\hline Primary Pump & 4 & (a) $190,000 \mathrm{lb}=$ & $760,000 \mathrm{lt}$ \\
\hline Pressure Vessel Head & 1 ea & $200,0001 \mathrm{~b}=$ & $200,000 \mathrm{lt}$ \\
\hline Pressure Vessel Bottom & 1 ea & $700,0007 \mathrm{~b}=$ & $700,000 \mathrm{lt}$ \\
\hline $\begin{array}{l}\text { Miscel laneous (i.e., tanks, } \\
\text { heat exchangers) }\end{array}$ & & & $\frac{1,000}{5,460}$ \\
\hline
\end{tabular}

(a) Labor cost to dismantle fuel building equipment (Reference 3, Figure G.2-3).

(b) Labor cost to dismantle auxiliary building equipment (Reference 3, Figure G.2-4).

(c) Weight of equipment in fuel and auxiliary buildings (Reference 3 , Table A.3-6). 


\section{REFERENCES}

1. Plan for Reevaluation of NRC Policy on Decommissioning of Nuclear Facilities, U.S. Nuclear Regulatory Commission, NUREG-0436, Rev. 1, December 1978.

2. Generic Environmental Impact Statement on Decommissioning Nuclear Facilities, U.S. Nuclear Regulatory Commission, NUREG-0586, to be published.

3. R. I. Smith, G. J. Konzek and W. E. Kennedy, Jr., Technology, Safety and Costs of Decomissioning a Reference Pressurized Water Reactor Power Station, prepared by Pacific Northwest Laboratory for U.S. Nuclear Regulatory Commission, NUREG/CR-0130, June 1978. (References in the text to pages, figures and tables prefaced by letters are to the appendices of this document.)

Addendum to Reference 3: R. I. Smith and L. M. Polentz, Technology, Safety and Costs of Decommissioning a Reference Pressurized Water Reactor Power Station, prepared by Pacific Northwest Laboratory for U.S. Nuclear Regulatory Commission, Addendum to NUREG/CR-013D, August 1979.

4. H. D. Oak et a1., Technology, Safety and Costs of Decomissioning a Reference Boiling Water Reactor Power Station, prepared by Pacific Northwest Laboratory for U.S. Nuclear Regulatory Commission, NUREG/CR-0672, to be published.

5. A. H. Schilling, H. E. Lippek, P. D. Tegeler and J. D. Easterling, Decommissioning Commercial Nuclear Facilities: A Review and Analysis of Current Regulations, prepared by Pacific Northwest Laboratory and BattelTe Human Affairs Research Centers for U.S. Nuclear Regulatory Commission, NUREG/CR-0671, August 1979.

6. Ninth Annual Occupational Radiation Exposure Report, 1976, U.S. Nuclear ReguTatory Commission, NUREG-0322, October 1977.

7. C. A. Pelletier, L. Simmons, M. Barbier and J. H. Keller, Compilation and Analys is of Data on Occupational Radiation Exposure Experienced at Operating Nuclear Power Plants, Atomic Industrial Forum, September 1974.

8. R. 0. Pohl, "Radiation Exposure in LWRs Higher Than Predicted," Nuclear Engineering Internationa 1, p. 36, February 1979.

9. A. Martin, "Occupational Radiation Exposure in LWRs Increasing, "Nuclear Engineering International, p. 32, January 1977.

10. Capital Cost: Pressurized Water Reactor Plant, U.S. Nuclear Regulatory Commission, NUREG-0241, June 1977.

11. Final Elk River Reactor Program Report, United Power Association, Elk River, MN 55330, November 1974. 
12. B. J. Davis, "Elk River Reactor Dismantling," Proceedings of the Conference on Decontamination and Decomissioning of ERDA Facilities, Idaho Fal1s, ID, August 19-21, 1975.

13. B. D. Redd, "WPPSS Nuclear Projects $1 \& 4$, Special Nuclear Coatings on Concrete, Reference SPUE-78-739, January 4, 1978," United Engineers and Constructors (part of back-up for U.E. and Constructors in files open to the public at Washington Public Power Supply System, Richland, WA 99352).

14. J. R. May, "Radioactive Waste Volume Reduction," Newport News Industrial Corporation, Power Engineering, October 1978.

15. A Survey and Evaluation of Handling and Disposing of Solid Low-Level Nuclear Fuel Cycle Wastes, AIF/NESP-008, D08 ES, 1977.

16. Environmental Survey of the Reprocessing and Waste Management Portions of the LWR Fuel Cycle, U.S. Nuclear Regulatory Commission, NUREG-0016, October 1976.

17. Report to the President by the Interagency Review Group on Nuclear Waste Management, TID-29442, March 1979.

18. H. W. Arrowsmith, J. L. Hooper, L. A. Charlot and R. P. Allen, Electropolishing as a Decontamination Process: Progress and Application, PNL-SA 6858, Battelle, Pacific Northwest Laboratories, Richland, WA, Apri1 1978.

19. W. J. Manion and T. S. LaGuardia, An Engineering Evaluation of Nuclear Power Reactor Decommissioning Alternatives, Atomic Industrial Forum, Inc., November 1976.

20. Charles H. Allen, J. M. Halter and R. G. Sullivan, "Contaminated Concrete Surface Layer Remova]," p. 12, Table II, Fourth International Symposium on Contamination Control, Washington, DC., September 10-13, 1978 (published by Plenum Press, 227 West 17th St., New York, NY 10011). 



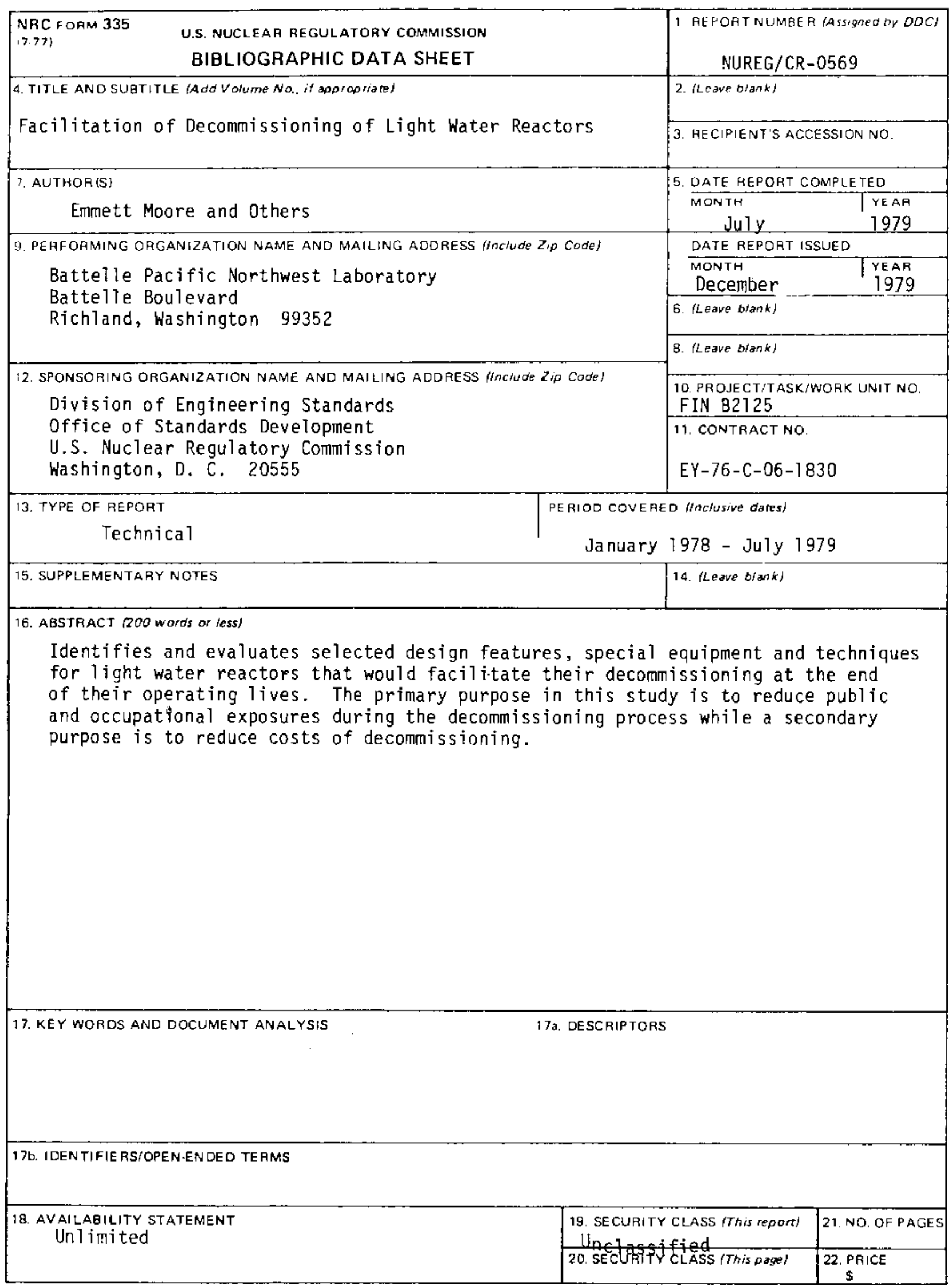




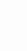

